OPEN ACCESS

Edited by:

Kai-Uwe Hinrichs,

University of Bremen, Germany

Reviewed by:

Yantao Liang,

Ocean University of China, China

Thomas Evans,

Massachusetts Institute

of Technology, United States

${ }^{*}$ Correspondence:

Sebastian I. Cantarero sebastian.cantarero@colorado.edu

Julio Sepúlveda

jsepulveda@colorado.edu

Specialty section:

This article was submitted to

Marine Biogeochemistry,

a section of the journal

Frontiers in Marine Science

Received: 05 March 2020

Accepted: 17 August 2020

Published: 22 September 2020

Citation:

Cantarero SI,

Henríquez-Castillo C, Dildar N,

Vargas $C A$, von Dassow $P$, Cornejo-D'Ottone M and Sepúlveda J (2020) Size-Fractionated Contribution

of Microbial Biomass to Suspended Organic Matter in the Eastern Tropical South Pacific Oxygen Minimum Zone.

Front. Mar. Sci. 7:540643.

doi: 10.3389/fmars.2020.540643

\section{Size-Fractionated Contribution of Microbial Biomass to Suspended Organic Matter in the Eastern Tropical South Pacific Oxygen Minimum Zone}

\author{
Sebastian I. Cantarero ${ }^{*}$, Carlos Henriquez-Castillo ${ }^{2,3}$, Nadia Dildar' ${ }^{1}$, \\ Cristian A. Vargas ${ }^{4,5}$, Peter von Dassow 4,6, Marcela Cornejo-D'Ottone ${ }^{4,7}$ and \\ Julio Sepúlveda ${ }^{1,4 *}$
}

\begin{abstract}
${ }^{1}$ Department of Geological Sciences and Institute of Arctic and Alpine Research, University of Colorado Boulder, Boulder, CO, United States, ${ }^{2}$ Laboratorio de Fisiología y Genética Marina (FIGEMA), Centro de Estudios Avanzados de Zonas Áridas (CEAZA), Coquimbo, Chile, ${ }^{3}$ Facultad de Ciencias del Mar, Universidad Católica del Norte, Coquimbo, Chile, ${ }^{4}$ Millenium Institute of Oceanography, Universidad de Concepción, Concepción, Chile, ${ }^{5}$ Coastal Ecosystems and Global Environmental Change Lab, Department of Aquatic Systems, Centre for Environmental Sciences EULA-Chile, Universidad de Concepción, Concepción, Chile, ${ }^{6}$ Department of Ecology, Pontificia Universidad Católica de Chile, Santiago, Chile, ${ }^{7}$ Escuela de Ciencias del Mar, Pontificia Universidad Católica de Valparaíso, Valparaíso, Chile
\end{abstract}

Cell membrane intact polar lipids (IPLS) are chemotaxonomic biomarkers whose abundances and distributions in water column environments reflect the living biomass of in situ microbial communities, and can be used to determine the relative contribution of distinct functional and phylogenetic groups to water column carbon stocks. The diversity of IPLS in marine environments is, however, vast, while our knowledge of their biological origins remains limited. Here, we study the distribution of IPLs in sizefractionated suspended organic matter from the oxygen minimum zone (OMZ) of the eastern tropical South Pacific (ETSP) off northern Chile. Canonical correspondence analyses of total IPL abundances and water column physiochemistry demonstrate distinct distributions of microbial sources associated with different geochemical regions in the water column (chlorophyll maximum, upper chemocline, lower chemocline, upper $\mathrm{OMZ}$, core OMZ, and mesopelagic region). Furthermore, the distribution of IPLs in free-living $(0.3-2.7 \mu \mathrm{m})$ and particle-attached $(2.7-53 \mu \mathrm{m})$ suspended organic matter differs, suggesting distinct biological sources in each size fraction. While some parallels exist, the diversity and distribution of IPLs in the OMZ system of the ETSP off northern Chile exhibited some unique features compared to other OMZ systems; for instance, we observed a significantly lower contribution of betaine lipids from phytoplanktonic sources, possibly reflecting a physiological response to severe $\mathrm{N}$-limitation in this area. The overall IPL abundance in the two size fractions also indicates a dominance of freeliving biomass in the $\mathrm{OMZ}$ and mesopelagic regions, suggesting that these areas of the water column could provide additional sources of submicrometer-sized organic 
carbon to deeper waters. This study improves the utility of IPLs as chemotaxonomic biomarkers by providing insight into the contrasting distributions of microbial biomass from different life modes (free-living and particle-attached). Our results suggest that microbial production in low oxygen environments may be more important to total water column carbon stocks than previously thought.

Keywords: intact polar lipids, oxygen minimum zone, marine biogeochemistry, biomarker, microbial biomass

\section{INTRODUCTION}

Lipids are a class of organic molecules ubiquitous to all forms of known life. The great chemical diversity of cell membrane intact polar lipids (IPLs) provides some phylogenetic specificity, which has been exploited in the mapping of planktonic and microbial communities in marine environments (Wakeham et al., 2007; Popendorf et al., 2011; Brandsma et al., 2012; Rush et al., 2012; Sollai et al., 2015). Given the susceptibility of their polar head groups to hydrolysis after cell death (White et al., 1979; Harvey et al., 1986; Petersen et al., 1991), the abundance of environmental IPLs is commonly interpreted to represent the occurrence of living cells, and is thus used to determine the in situ abundances of different metabolic and biosynthetic pathways (e.g., Schubotz et al., 2009; Van Mooy and Fredricks, 2010; Wakeham et al., 2012; Schubotz et al., 2018). While the stability of polar head groups has been questioned in sediments (Schouten et al., 2010; Logemann et al., 2011), the short residence time of particles in water column samples (Moran and Buesseler, 1992) allows the use of IPLs to study microbial abundances and contribution to carbon stocks in suspended particles.

Marine planktonic IPLs are mostly comprised of several distinct classes of amino/betaine, glycol, and phospholipids that are predominantly produced by algae, a combination of cyanobacteria/algae, and bacteria, respectively (Goldfine, 1984; Dembitsky, 1996; Harwood, 1998; Wada and Murata, 1998; Suzumura, 2005). Additionally, the predominance of polyunsaturated fatty acids in eukaryotic cells (Volkman et al., 1989), the preferential synthesis of odd-chain fatty acids in bacterial membranes (Schubotz et al., 2009; Van Mooy and Fredricks, 2010), the presence of isoprenoidal lipids in archaea (Pearson and Ingalls, 2013), as well as the differing stereochemistry of ether and ester linkages between bacterial and archaeal lipids (Weijers et al., 2006; Valentine, 2007), are used to assess distinct biological sources in the environment. Furthermore, empirical relationships between water column chemistry, cell sorting techniques, and IPL concentrations have served useful to determine potential biological sources (Van Mooy and Fredricks, 2010; Wakeham et al., 2012; Schubotz et al., 2018). Other specific IPLs in marine environments include archaeal glyco- and phospho- glycerol dialkyl glycerol tetraethers (GDGTs; Pitcher et al., 2011; Elling et al., 2014; Sollai et al., 2015) as well as anammox bacteria ladderane phospholipids (Sinninghe Damsté et al., 2005; Boumann et al., 2006; Rush et al., 2012).

Microbial activity has significant global effects on the biogeochemical structure of the water column (Arrigo, 2005; Falkowski et al., 2008), particularly via the extensive remineralization of organic matter and the transfer of carbon between the surface and subsurface ocean (termed the "microbial loop" by Pomeroy, 1974; Azam et al., 1983; Azam, 1998). The microbial loop also controls the cycling of nitrogen (Herbert, 1999; Jetten, 2008; Lam and Kuypers, 2011; Thamdrup, 2012), phosphorus (Dyhrman et al., 2007), and sulfur (Sievert et al., 2007; Canfield et al., 2010). Oxygen minimum zones (OMZs) are hot spots of marine microbial diversity (Ulloa et al., 2012; Wright et al., 2012) containing chemoautotrophic processes that can have a significant contribution to carbon fluxes (see Taylor et al., 2001; Lengger et al., 2020). The adsorption of fine organic particles onto ballasted minerals, or the formation of aggregates (marine snow) greatly increases their sinking rates through the water column (Passow and De La Rocha, 2006; De La Rocha et al., 2008; Wilson et al., 2012) thus providing a mechanism for the export of submicron organics to the deep sea. Indeed, previous biomarker work suggests that a significant proportion of exported particulate organic matter (POM) to the mesopelagic region in oligotrophic waters may be from a submicron component (Close et al., 2013). However, POM has historically been collected using $0.7 \mu \mathrm{m}$ filters, which may not capture all average-sized bacterial cells $(0.2-0.6 \mu \mathrm{m}$; Pomeroy et al., 2007), and thus underestimate the contribution of microbial organic matter. Lipidomic and metagenomic studies in these systems indicate that the composition and abundance of microbial biomass differs between micron-scale (typically $>1-$ $3 \mu \mathrm{m}$ ) and submicron-scale (ranging from 0.2 to $0.7 \mu \mathrm{m}$ ) POM fractions (Close et al., 2014; Ganesh et al., 2014, 2015; Duret et al., 2015; Matys et al., 2017). Thus, the interpretation of individual IPL sources, and their use to reconstruct microbial distributions in the environment, may be complicated either by the occurrence of distinct metabolic niches in large vs. submicron POM, by multiple biological sources for common compounds, or by the potentially rapid export of particles via ballasting.

The eastern tropical South Pacific (ETSP) harbors one of the largest volumes of hypoxic waters in the world (Helly and Levin, 2004; Paulmier and Ruiz-Pino, 2009). The subsurface waters along the Humboldt Current off northern Chile and Perú are characterized by reduced circulation and ventilation (Czeschel et al., 2011; Thamdrup et al., 2012; Karstensen and Ulloa, 2019) as well as intense aerobic decomposition of detrital organic matter (Pantoja et al., 2004; Canfield et al., 2010) fueled by the upwelling of nutrient-rich water masses and high productivity in surface waters (Daneri et al., 2000). These processes lead to the occurrence of a marked OMZ $(<20 \mu \mathrm{M})$ between $\sim 50-100$ and 300-400 m (De Pol-Holz et al., 2009; Fuenzalida et al., 2009; Ulloa and Pantoja, 2009) that is functionally anoxic (Thamdrup et al., 2012; Ulloa et al., 2012). The exact depth and structure of the oxycline is determined by a combination of $\mathrm{O}_{2}$ production via 
photosynthesis, stratification and depth of the wind mixed layer, and aerobic respiration rates, in addition to mesoscale physical processes such as eddies that can also replenish the subsurface with $\mathrm{O}_{2}$ (Ulloa et al., 2012).

Here, we study the differences in distribution and abundance of IPLs in size-fractionated suspended organic matter, a "particleattached" fraction $(2.7-53 \mu \mathrm{m})$ and a "free-living" fraction (0.3$2.7 \mu \mathrm{m})$, through waters of the OMZ in the ETSP off the coast of northern Chile. While these size fractions may include some overlap between bacterial cells (typically $<1 \mu \mathrm{m}$; see Ducklow, 2001; Pomeroy et al., 2007) attached to larger organic substrates, or eukaryotic picoplankton cells contributing to the free-living fraction ( $\sim 2 \mu \mathrm{m}$; see Finkel et al., 2010), this investigation is meant to broadly define differences in the IPL composition between both planktonic life modes. We aim to demonstrate the utility of size-fractionated IPLs distributions in POM to improve the characterization of in situ microbial planktonic community composition across strong geochemical gradients, in addition to better quantify their potential contribution to water column carbon stocks. Additionally, we present an exhaustive catalog of predominantly bacterial and eukaryotic IPLs that expands the ever growing database of microbial signatures in marine OMZs.

\section{MATERIALS AND METHODS}

\section{Sampling and Physicochemical Water Analyses}

Samples of suspended organic matter were collected from two stations off the coast of Iquique, northern Chile $\left(\sim 20^{\circ} \mathrm{S}\right.$; Figure 1) during the LowpHOX-2 Cruise (February 4-6, 2018) aboard the AGS-61 Cabo de Hornos. Samples were collected from a depth profile along a more nearshore station (T3, $30 \mathrm{~km}$ from the coast) where the OMZ exhibited a shallow oxycline $(\sim 15-$ $55 \mathrm{~m}$ ), denoted henceforth as "nearshore station," in addition to a second station further offshore (T5, $\sim 80 \mathrm{~km}$ from the coast) with a slightly deeper oxycline $(\sim 25-60 \mathrm{~m})$, denoted henceforth as "offshore station." Physicochemical profiles were measured using a Seabird SBE-911 CTD system, equipped with an SBE 43 oxygen sensor and fluorometer, in addition to 2410 L General Oceanics Niskin Bottles. Chlorophyll $a$ concentration was estimated fluorometrically as described by Parsons et al. (1984) and dissolved inorganic $\mathrm{N}$ (nitrite, $\mathrm{NO}_{2}{ }^{-}$and nitrate, $\mathrm{NO}_{3}{ }^{-}$) and phosphate $\left(\mathrm{PO}_{4}{ }^{3-}\right)$ were analyzed using protocols established by Grasshoff et al. (2009). Temperature, salinity, oxygen, and fluorescence sensors were calibrated before the cruise by Seabird Scientific ${ }^{\circledR}$, WA, United States (2nd half of 2017). Onboard, all sensors were carefully maintained after each cast to avoid salt accumulation. Oxygen and fluorescence data were checked and corrected with in situ values analyzed through Winkler titration method (Carpenter, 1965) and fluorometric analyses, respectively at standard depths $(2,10,25,50,100$, and $250 \mathrm{~m})$. We collected an entire rosette cast $(200 \mathrm{~L})$ for IPL analysis at six discrete depths: chlorophyll maximum $(\sim 10 \mathrm{~m})$, upper chemocline $(\sim 25 \mathrm{~m})$, lower chemocline $(\sim 45 \mathrm{~m})$, upper OMZ $(\sim 60 \mathrm{~m})$, core OMZ $(\sim 250 \mathrm{~m})$, and mesopelagic zone $(\sim 750 \mathrm{~m})$. Sea water was transferred to a large, high-density polyethylene drum and then filtered through pre-combusted, $142 \mathrm{~mm}$ Sterlitech (D1420) and Advantec glass fiber filters (GF75142MM) of 2.7 and $0.3 \mu \mathrm{m}$ pore sizes, respectively. Water samples were prefiltered through a $53 \mu \mathrm{m}$ mesh to remove large organisms. Here, we refer to the $2.7-53 \mu \mathrm{m}$ size fraction as "particle-attached," and to the $0.3-2.7 \mu \mathrm{m}$ size fraction as "free-living" microbes, although we recognize that some overlap between both fractions is likely. All samples were wrapped in combusted aluminum foil and shipped frozen to the Organic Geochemistry Laboratory at the University of Colorado, Boulder for IPL extraction and analysis. Additional water column filtrates (1-2 L) were collected for particulate organic carbon (POC) and particulate organic nitrogen (PON) using pre-combusted $25 \mathrm{~mm}$ diameter glass fiber filters with a $0.7 \mu \mathrm{m}$ pore size. The same water was subsequently filtered through $25 \mathrm{~mm}$ diameter glass fiber filters with a $0.2 \mu \mathrm{m}$ pore size for dissolved organic carbon (DOC).

\section{Lipid Extraction and Analysis}

Intact polar lipids were extracted from glass fiber filters via a modified version (Wörmer et al., 2013) of the original Bligh and Dyer Extraction method (Bligh and Dyer, 1959). Samples were extracted by ultrasonication a total of five times with three different extraction mixtures. Two extractions were performed using Dichloromethane/Methanol/Phosphate $\operatorname{buffer}_{(a q)} \quad[1: 2: 0.8, \mathrm{v}: \mathrm{v}: \mathrm{v}]$, with the Phosphate buffer adjusted

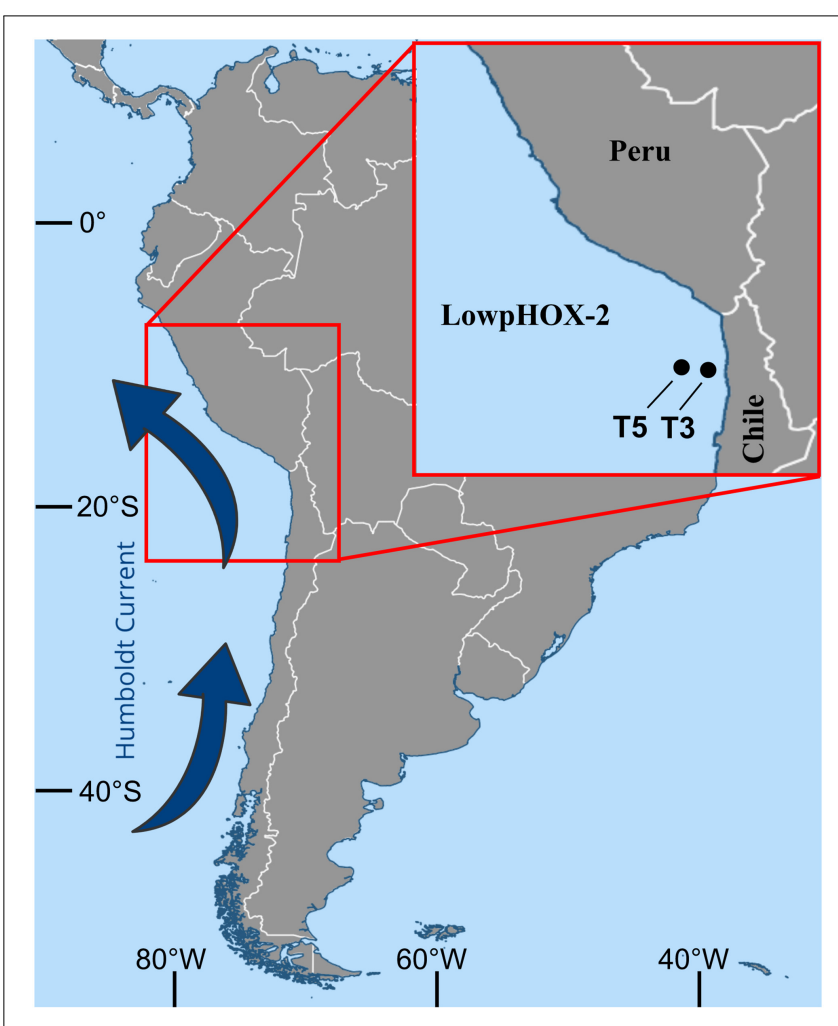

FIGURE 1 | Study area marking the location of Stations T3 (nearshore) and T5 (offshore) along the Humboldt Current in the ETSP off northern Chile. 
to a $\mathrm{pH}$ of $\sim 7.4$. Two extractions were subsequently prepared with Dichloromethane/Methanol/Trichloroacetic acid $\operatorname{buffer}_{(a q)}$ [1:2:0.8, v:v:v] with the 5\% Trichloroacetic acid buffer at a final $\mathrm{pH}$ of $\sim 2$. A final extraction was prepared with Dichloromethane/Methanol [1:5, v:v]. We added $2 \mu \mathrm{g}$ of $\mathrm{C}_{16} \mathrm{PAF}$ (see Supplementary Table 1) to each extraction as internal standard. Following extraction, samples were concentrated under a gentle flow of $\mathrm{N}_{2}$ using a Turbovap, re-dissolved in 9:1 Dichloromethane:Methanol, (v/v), sonicated, vortexed, and then filtered using a $0.45 \mu \mathrm{m}$ polytetrafluoroethylene (PTFE) syringe filter. Before analysis, an aliquot representative of $\sim 1 \%$ of the total lipid extract (TLE) was transferred into a $2 \mathrm{~mL}$ vial with an insert, and re-dissolved in $100 \mu \mathrm{l}$ of 9:1 Dichloromethane:Methanol, (v/v). The coupled identification and quantification of IPLs was achieved using a Thermo Scientific Ultimate 3000 High Performance Liquid Chromatography interphase to a Q Exactive Focus Orbitrap-Quadrupole High Resolution Mass Spectrometer (HPLC-HRMS) via electrospray ionization (ESI) in positive mode. We used the chromatographic conditions described by Wörmer et al. (2013); i.e., an Acquity BEH Amide $1.7 \mu \mathrm{m}, 2.1$ by $150 \mathrm{~mm}$ column, flow rate of $0.4 \mathrm{~mL} / \mathrm{min}$ with two mobile phases. Mobile phase A consisted of Acetonitrile:Dichloromethane [75:25, v:v] with $0.01 \%$ formic acid and $0.01 \% \mathrm{NH}_{4} \mathrm{OH}$; Mobile phase B consisted of Methanol: $\mathrm{H}_{2} \mathrm{O}$ [50:50, v:v] with $0.4 \%$ formic acid and $0.4 \% \mathrm{NH}_{4} \mathrm{OH}$. Mobile phases were proportioned under the following gradients: 0 min: $1 \%$ B, 2.5 min: $1 \%$ B, 4 min: 5\%, $22.5 \mathrm{~min}: 25 \%$ B, $26.5 \mathrm{~min}: 40 \%$ B, 27.5 min: $40 \%$ B. Column temperature was kept at $40^{\circ} \mathrm{C}$ and samples were injected in Dichloromethane:Methanol [9:1, v:v]. Electrospray ionization settings were optimized for maximum intensity across all measured IPL classes under the following conditions: auxiliary gas heater temperature $425^{\circ} \mathrm{C}$, capillary temperature $265^{\circ} \mathrm{C}$, spray voltage $3.50 \mathrm{kV}$, sheath gas flow 35 arbitrary units (AU), aux gas flow 13 AU, S-lens RF level 55.0 AU. The instrument was constantly calibrated for mass resolution and accuracy using the Pierce ${ }^{\text {TM }}$ LTQ Velos ESI Positive Ion Calibration Solution (88323). Samples were analyzed in full scan mode to obtain an untargeted screening (or lipidomic profile) of each sample, in addition to targeted MS/MS mode for compound identification via diagnostic fragmentation patterns (Sturt et al., 2004; Schubotz et al., 2009; Wakeham et al., 2012). IPLs were identified by their exact masses, polar head groups, the number of carbon atoms and unsaturation in the core structure, and their retention times. While other studies have analyzed IPLs under both positive and negative ionization modes to determine the fatty acid composition in the core lipid structures, we took advantage of the high resolution of our mass spectrometer to focus on the diversity of head group combinations with total carbon atoms and unsaturation only.

Quantification of IPLs was achieved with a combination of an internal standard ( $\mathrm{C}_{16} \mathrm{PAF}$, Avanti Lipids) and external calibration standards consisting of 17 different IPL classes (16 IPL-Mix, Avanti Lipids, and Matreya LLC main phospholipid of Thermoplasma acidophilum; see Supplementary Table 1). The intensity of each individual IPL identified in the HPLC-ESIHRMS analysis was calibrated to a linear regression between peak areas and known concentrations of the same lipid class (or the most similar molecular structure) across a 5-point dilution series (0.001-2.5 ng/ $\mu \mathrm{l})$. Samples were also spiked with known concentrations of deuterated IPL standards (Avanti Lipids: d7PC, d7-PE, d7-PG, and d9-DGTS) to correct for possible sample matrix effects on ionization efficiency, and to check for consistency in retention times.

\section{POC, DOC, and PON Analyses}

Filters were dried overnight at $60^{\circ} \mathrm{C}$ and split for duplicate analyses and packed into tin boats. Total particulate organic carbon and nitrogen was measured using a Thermo Scientific Elemental Analyzer - Isotope Ratio Mass Spectrometer at the CU Boulder Earth Systems Stable Isotope Lab. Purified acetanilide standards were measured for external calibration and drift corrections with a carbon and nitrogen analytical precision between $1.1-2.2 \%$ and $0.6-2.2 \%$, respectively, across all analysis runs. Dissolved organic carbon was performed using a modified OI Analytical model 1030 wet TOC analyzer (analytical precision of $1.8 \%$ ), with a model 1088 autosampler at the Ján Veizer Stable Isotope Laboratory at the University of Ottawa.

\section{DIC, $\mathrm{pH}_{T}$, and $\mathrm{pCO}_{2}$}

Samples for total alkalinity $\left(\mathrm{A}_{T}\right)$ were poisoned with $50 \mu \mathrm{L}$ of saturated $\mathrm{HgCl}_{2}$ solution and $\mathrm{A}_{T}$ was determined using the open-cell titration method (Dickson et al., 2003) with an automatic Alkalinity Tritrator (Model AS-ALK2 Apollo SciTech). All samples were analyzed at $25^{\circ} \mathrm{C}\left( \pm 0.1^{\circ} \mathrm{C}\right)$ with temperature regulation using a water-bath. DIC samples were collected in $250 \mathrm{~mL}$ Wheaton ${ }^{\circledR}$ glass bottles and preserved with $50 \mu \mathrm{L}$ saturated $\mathrm{HgCl}_{2}$ solution. Samples were acidified with $10 \%$ phosphoric acid and the evolved $\mathrm{CO}_{2}$ measured with a LICOR 6262 non-dispersive infrared gas analyzer. Analytical accuracy was controlled against a certified reference material (CRM, supplied by Andrew Dickson, Scripps Institution of Oceanography, San Diego, CA, United States; Batch \#166) and the $A_{T}$ repeatability averaged $2-3 \mu \mathrm{mol} \mathrm{kg}{ }^{-1}$. Temperature, salinity, $\mathrm{A}_{T}$ and DIC data were used to calculate $\mathrm{pH}_{T}$ (total scale), aqueous carbon dioxide $\left(\mathrm{CO}_{2}\right.$-aq), and partial pressure $\left(p \mathrm{CO}_{2}\right)$. Analyses were performed using $\mathrm{CO}_{2} \mathrm{SYS}$ software for MS Excel (Pierrot et al., 2006) set with Mehrbach solubility constants (Mehrbach et al., 1973) refitted by Dickson and Millero (1987), the $\mathrm{KHSO}_{4}$ equilibrium constant determined by Dickson (1990) was used for all calculations.

\section{Lipid Diversity and Canonical Correspondence Analysis}

Lipid richness through the water column was estimated using the Shannon index based on equal completeness, as described in Chao et al. (2012) using the iNEXT package v2.0.19 in $\mathrm{R}$ environment. A canonical correspondence analysis (CCA) was carried out to elucidate the relationships between IPLs distribution and physicochemical conditions $\left(\mathrm{O}_{2}, \mathrm{DOC}, \mathrm{DIC}\right.$, $\left.\mathrm{pCO}_{2}, \mathrm{pH}, \mathrm{NO}_{3}{ }^{-}, \mathrm{NO}_{2}{ }^{-}, \mathrm{PO}_{4}{ }^{3-}, \mathrm{Chl}-\mathrm{a}\right)$. Triplots include sites, response variables (IPL concentrations) and explanatory variables (environmental data). The site scores are weighted sums of IPLs. The distribution of individual compounds within a 
given IPL class was also explored via CCAs combining intra-class abundances and water column physiochemistry.

\section{RESULTS}

\section{Physicochemical Characterization of the Water Column and IPL Concentrations}

Oxygen levels varied from $6 \mathrm{ml} / \mathrm{L}$ at the surface to below detection limit $(\sim 0.012 \mathrm{~mL} / \mathrm{L})$ in the OMZ (Figure 2A). A shallow oxycline $(15-50 \mathrm{~m})$ was evident in the nearshore station, while a slightly deeper oxycline $(25-60 \mathrm{~m})$ was observed in the offshore station. The functionally anoxic OMZ impinged the euphotic zone and reached a depth of at least $250 \mathrm{~m}$ in both stations. Below this depth, waters remained $<0.3 \mathrm{~mL} / \mathrm{L} \mathrm{O}_{2}$ until at least $500 \mathrm{~m}$. Chlorophyll concentration varied between 3.12 and $3.85 \mathrm{mg} / \mathrm{m}^{3}$ in the chlorophyll maximum at $\sim 10$ and $25 \mathrm{~m}$ in the nearshore and offshore stations, respectively, and quickly dropped to $<0.5 \mathrm{mg} / \mathrm{m}^{3}$ by a depth of $50 \mathrm{~m}$ (Figure $2 \mathrm{~A}$ ).

The vertical distribution of nutrient species showed minimum concentrations of $\mathrm{NO}_{3}{ }^{-}(0-0.65 \mu \mathrm{mol} / \mathrm{L}), \mathrm{NO}_{2}{ }^{-}(\sim 0 \mu \mathrm{mol} / \mathrm{L})$, and $\mathrm{PO}_{4}{ }^{3-}(\sim 1.0 \mu \mathrm{mol} / \mathrm{L})$ in the surface and along the chlorophyll maximum (Figure 2B). The concentration of these nutrients increased significantly through the oxycline, with $\mathrm{PO}_{4}{ }^{3-}$ maintaining elevated concentrations through the anoxic core and into the mesopelagic region $(\sim 3 \mu \mathrm{mol} / \mathrm{L}) . \mathrm{NO}_{3}{ }^{-}$ increased to $15-20 \mu \mathrm{mol} / \mathrm{L}$ in the oxycline, with a secondary local minimum in the anoxic core $(10-15 \mu \mathrm{mol} / \mathrm{L})$, and maximum concentrations of $>35 \mu \mathrm{mol} / \mathrm{L}$ in the mesopelagic region. $\mathrm{NO}_{2}{ }^{-}$remained depleted until OMZ waters, reaching maximum concentrations of $(5-6 \mu \mathrm{mol} / \mathrm{L})$ in the anoxic core, and then returning to nearly absent levels in the mesopelagic region. A summary of the water column chemistry data incorporated into statistical analyses is shown in Supplementary Table 2.

POC and PON showed maximum concentrations (340$500 \mu \mathrm{g} / \mathrm{L}$ and $68-80 \mu \mathrm{g} / \mathrm{L}$, respectively) around the chlorophyll maximum ( $\sim 10-25 \mathrm{~m}$; Figure $2 \mathrm{C})$. The concentrations decreased rapidly through the chemocline and reached minimum values of $\sim 30 \mu \mathrm{g} / \mathrm{L} \mathrm{POC}$ and $2.5-4 \mu \mathrm{g} / \mathrm{L}$ PON in the mesopelagic region. The $\mathrm{C} / \mathrm{N}$ ratio varied from $\sim 5$ to 7 in the upper $50 \mathrm{~m}$ of the water column and increased with depth to maximum values $\sim 7.5$ to 12 between 100 and $750 \mathrm{~m}$ (Figure 2D).

Total IPL concentrations (normalized by liter of filtered seawater) showed an exponential decay with depth, with maximum values in surface waters $(\sim 4,800-7,100 \mathrm{ng} / \mathrm{L})$ and minimum values in the mesopelagic region $(\sim 140-180 \mathrm{ng} / \mathrm{L}$; Figure 2E). The concentration of IPLs normalized by POC ( $\mu \mathrm{g} \mathrm{IPL} / \mu \mathrm{g}$ POC) showed maximum values in the chemocline $(>0.02 \mu \mathrm{g} \mathrm{IPL} / \mu \mathrm{g}$ POC), while the upper and core OMZ exhibited values that are comparable and even larger than those in the chlorophyll maximum (Figure 2F). The mesopelagic region, on the other hand, showed the lowest contribution of IPLs to the POC pool $(<0.01 \mu \mathrm{g}$ IPL/ $\mu \mathrm{g}$ POC). The relative abundance of IPLs in the free-living fraction relative to the particle-attached fraction ([free-living IPLs]/[total IPLs]) showed generally lower values in the surface ocean $(10-25 \%$ of total IPLs), and it broadly increased with depth through the OMZ and showed greatest values in the mesopelagic region ( $\sim 90 \%$ of total IPLs; Figure 2G). We also observed spatial variability in freeliving fractional abundances among the two stations (Figure 2G), with the most contrasting trends observed in the chlorophyll maximum and along the chemocline. Finally, the lipid richness as calculated by the Shannon index indicated greatest IPLs diversity in the surface and secondary maxima in the OMZ (see Supplementary Table 3).

\section{CCAs of IPL Class Distribution}

The distribution of total IPLs as categorized by polar head group classes remained largely consistent between both stations within individual size fractions aside from some variability within the relative abundances of glycolipid classes in the photic zone (Figure 3). The triplot for the CCA showed a spatial structuring in the diversity and distribution of IPLs in response to the environmental constraints (Figure 4), with well-defined

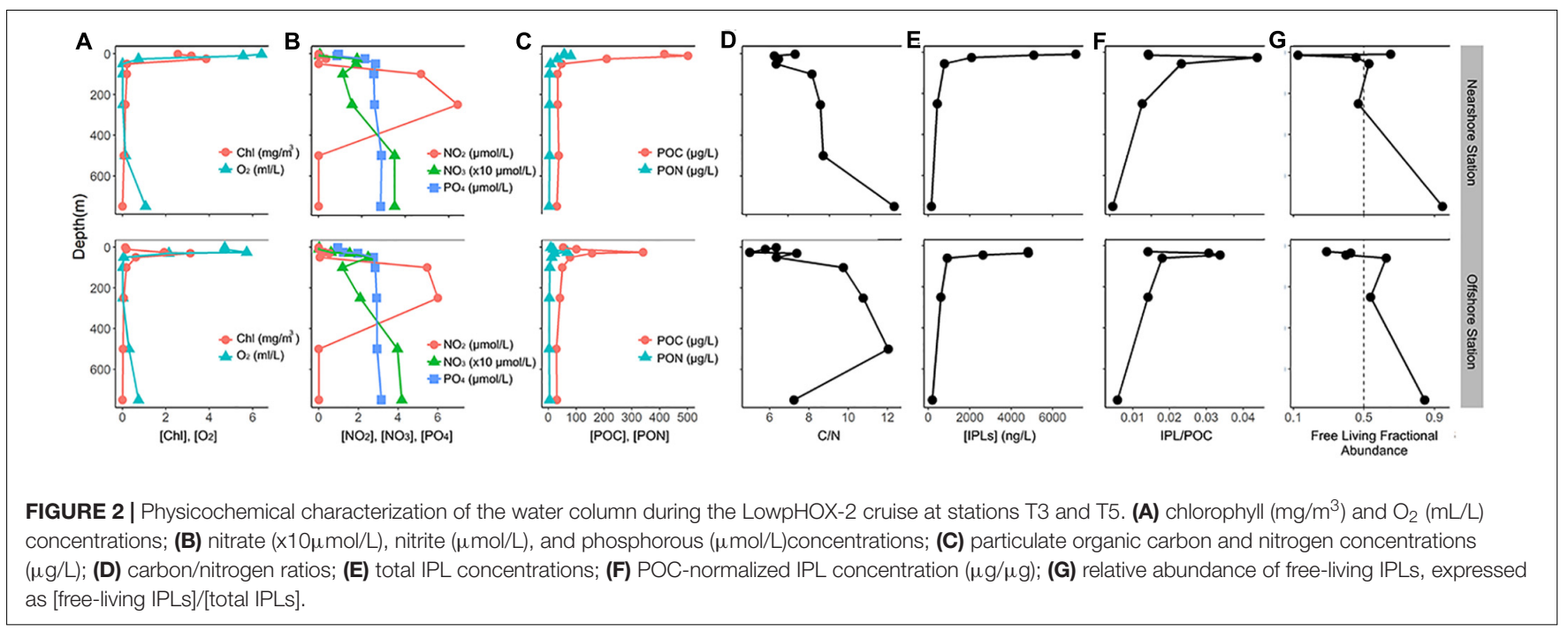




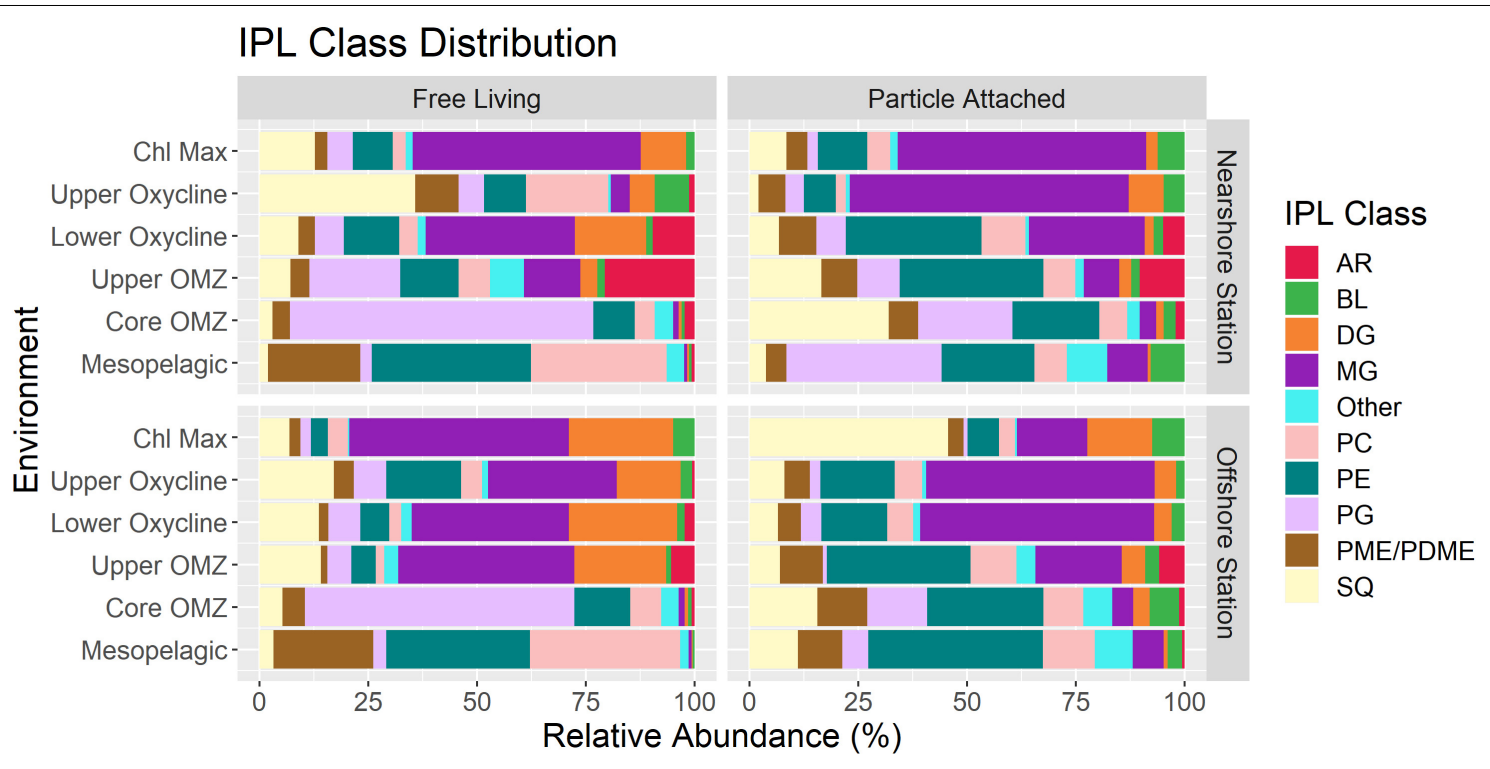

FIGURE 3 | Relative abundance of individual IPL classes in each size fraction and sampling station.

IPL groupings by geochemical regions (Figures 4, 5). This includes (a) a prevalence of glycolipids and betaine lipids with high chlorophyll, $\mathrm{pCO}_{2}$, and oxygen in surface waters, (b) a predominance of phospholipids associated with high DOC, $\mathrm{NO}_{3}{ }^{-}$and $\mathrm{PO}_{4}{ }^{3-}$ in subsurface waters below the chlorophyll maximum, and (c) a predominance of archaeal lipids clustered closely to high $\mathrm{NO}_{2}{ }^{-}$concentrations in the lower oxycline and oxygen minimum zone.

\section{Glycolipid Distribution}

Particle-associated IPLs in both sites showed significant abundances of glycolipids SQDG (Sulfoquinovosyldiacylglycerol) and MGDG (Monogalactosyldiacylglycerol) at all depths $(\sim 25-$ $75 \%$; Figure 3), with generally higher glycolipid contributions (MG, DG; Diglycosyldiacylglycerol, SQ) in the surface and oxycline than at depth. Free-living IPLs showed an even more pronounced dominance of glycolipids (MG, SQ, DG) in the chlorophyll maximum and oxycline $(\sim 70 \%)$ and were drastically reduced in the core $\mathrm{OMZ}$ and mesopelagic regions ( $<5 \%$; Figure 3).

A total of 20 unique MGDG molecules were detected in the ETSP, which showed greatest relative abundance in the chlorophyll maximum (up to $60 \%$ of the total IPL yield) and oxycline in both size fractions. While the particle-attached fraction was comprised of up to $15 \%$ MGDGs in the mesopelagic, MGDGs were nearly absent in the free-living fraction from both the core OMZ and mesopelagic regions. One of the most abundant MGDGs (30:1; up to $40 \%$ of the total IPL yield, see Figures 6A,B) in the particle-attached fraction clusters closely with chlorophyll concentrations, as do most MGDGs (Figure 7B). However, in the free-living fraction the clustering of this same molecule (as well as the majority of MGDGs) occurred along high $\mathrm{NO}_{2}{ }^{-}$and $\mathrm{pCO}_{2}$ (Figure $7 \mathbf{A}$ ).
A total of 20 DGDGs in the ETSP contribute up to 25\% of the IPL yield, largely confined to the photic zone in both size fractions, and with the greatest contribution found in the free-living fraction of the offshore station (Figure 3). The most abundant molecule amongst in the photic zone (DGDG30:0; Figures $6 \mathbf{A}, \mathbf{B}$ ) is closely correlated to chlorophyll and $\mathrm{O}_{2}$ concentrations amongst free-living IPLs (Figure 7C), but in the particle-attached fraction it is associated with high $\mathrm{pCO}_{2}$ and moderate $\mathrm{PO}_{4}{ }^{3-}$ and $\mathrm{NO}_{2}{ }^{-}$concentrations (Figure $7 \mathrm{D}$ ). The core $\mathrm{OMZ}$ and mesopelagic region exhibited a low contribution of DGDGs ( $<2 \%$ of total IPLs).

A total of 17 SQDGs were detected in the ETSP, and their relative abundance to the total IPL pool was highly variable (Figure 3). The free-living fraction is consistent between stations, with maximum contributions (15-30\%) found in the chlorophyll maximum and the upper oxycline. The particle-attached fraction shows more variability between stations. SQDGs make up 55\% of the total IPL pool in the offshore station chlorophyll maximum and $40 \%$ of the total IPL pool in the nearshore station core OMZ. The 2 most abundant SQDGs in the free-living fraction (28:0 and 30:0; Figures 6A,B) are associated with both high chlorophyll and $\mathrm{NO}_{2}{ }^{-}$concentrations, but have a negative correlation to chlorophyll in the particle-attached fraction (Figures 7E,F). The distribution of SQDGs in both fractions showed an increase in the contribution of SQDG-29:0 at depth (see Supplementary Figure $1 \mathrm{C}$ ) and a strong correlation with $\mathrm{NO}_{2}{ }^{-}$(Figures 7E,F).

\section{Phospholipid Distribution}

Phospholipids (PG; Phosphatidylglycerol, PE; Phosphatidylethanolamine, PC; Phosphatidylcholine, PME/PDME; Phosphatidyl(di)methylethanolamine) were prevalent throughout the water column and increased from $<10 \%$ in surface waters to 75 and $95 \%$ of the total IPL pool in the core $\mathrm{OMZ}$ and mesopelagic region, respectively. 


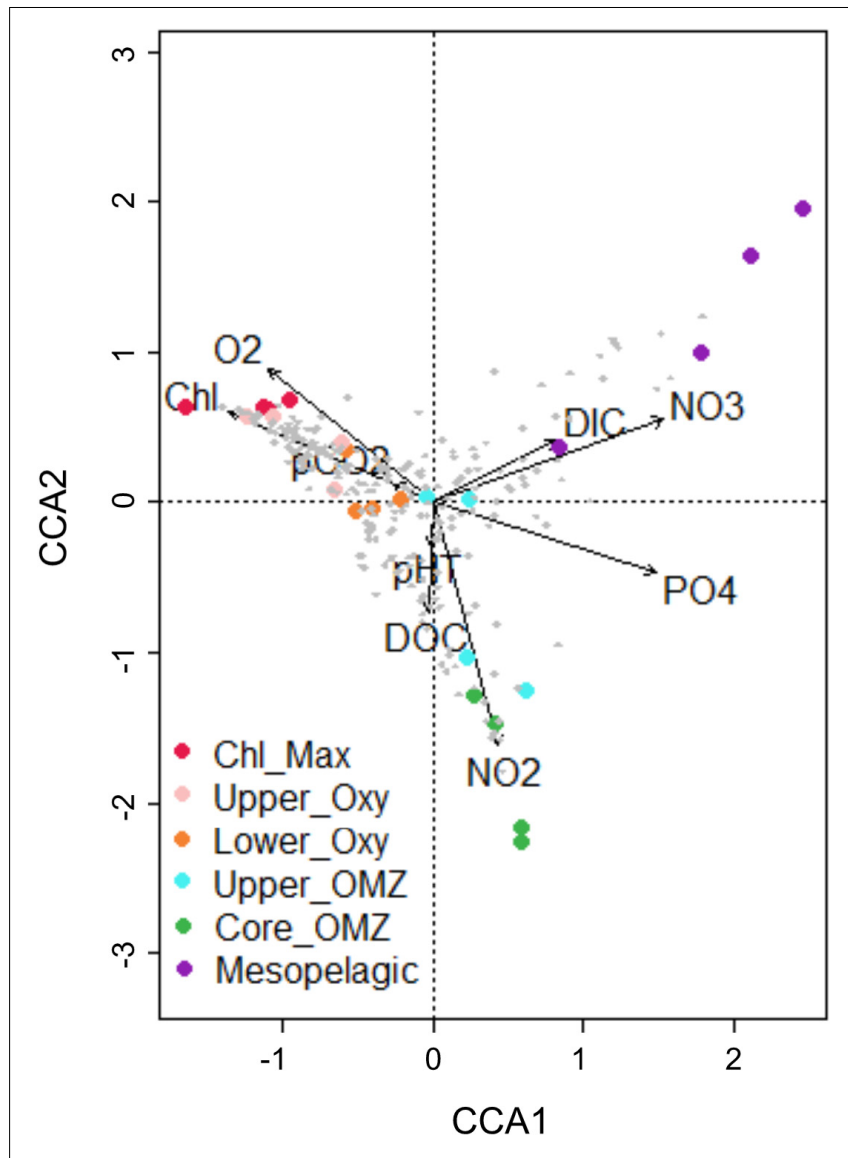

FIGURE 4 | Canonical correspondence analysis (CCA) of total IPL abundances and water column chemistry in both size fractions and sampling stations.

PGs were amongst the least diverse IPL class in the ETSP (13 compounds) molecules detected. Their contribution to the total free-living IPL pool ranged from $<5 \%$ in the chlorophyll maximum to $60-70 \%$ in core OMZ waters and $<5 \%$ in the mesopelagic region (Figure 3). Similarly, the particle-attached fraction demonstrated a significant relative contribution of PGs in the OMZ $(\sim 15-25 \%)$ and mesopelagic (5-10\%) waters. In addition, of the most abundant PGs in either fraction (i.e., 32:0, 33:1, and 34:3; Figures 6A,B) only 32:0 in the free-living fraction showed a strong association with chlorophyll in the surface (Figures 8A,B).

A high diversity of PEs were detected in the ETSP (24 compounds; see Supplementary Figure 2). PEs made up a small proportion of the total IPL pool in both fractions in the chlorophyll maximum and upper oxycline (5-10\%; Figure 3), however their relative abundance increased in the oxycline and below, reaching maximum values in OMZ waters (1525\%; Figure 3). Notably, the most abundant PEs (31:0 and 33:0; Figures 6A,B) in the photic zone were nearly absent in the free-living fraction in the core OMZ (see Supplementary Figure 2C) but remained a major contributor in the particleattached fraction.

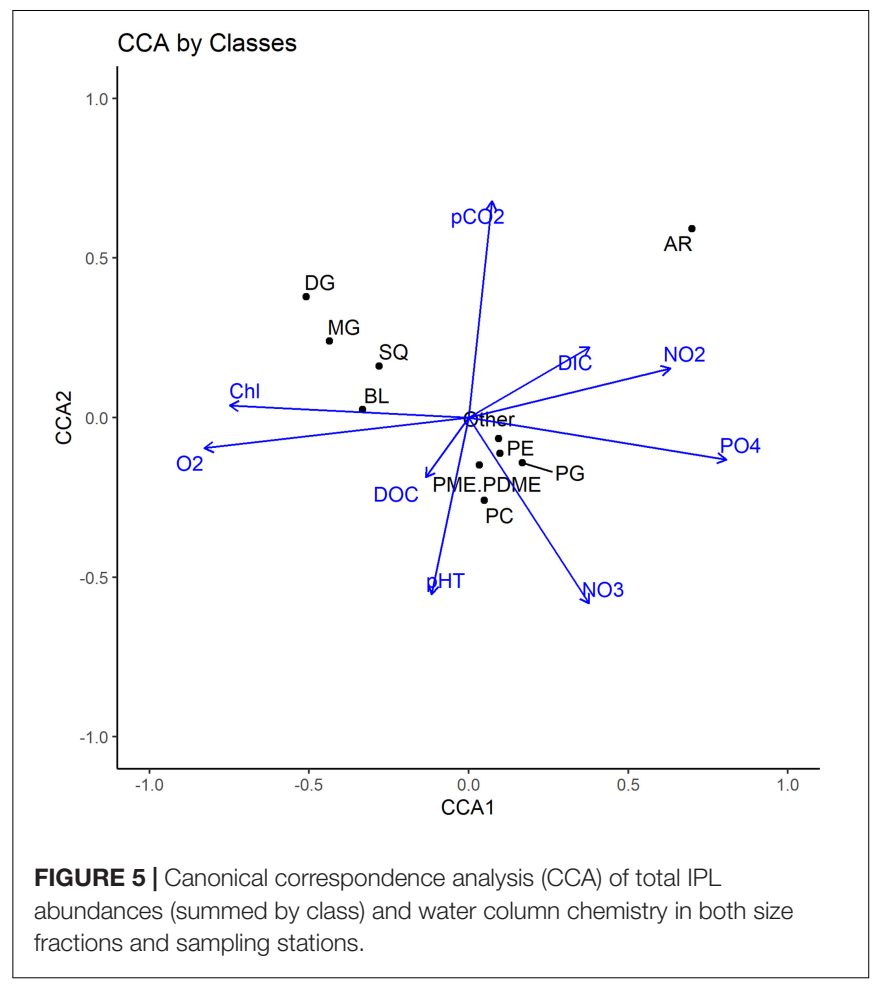

The distribution of PCs in the ETSP was highly variable with a $<5 \%$ contribution to total IPL yields in the chlorophyll maximum, yet $\sim 40$ and $15 \%$ in the free-living and particleattached fractions (respectively) within the mesopelagic region (Figure 3). However, the diversity of this lipid class (38 compounds) was high across all depths (Supplementary Figure 2A). In the chlorophyll maximum and upper oxycline, the relative abundance of PCs were dominated by PC-30:0, which clustered between $\mathrm{O}_{2}$ and $\mathrm{NO}_{3}{ }^{-}$in a CCA of the freeliving fraction (Figure 8E), yet it correlated closely with $\mathrm{O}_{2}$ and chlorophyll in the particle-attached fraction (Figure 8F). Most particle-attached PCs correlated to high chlorophyll, or moderate concentrations of both $\mathrm{NO}_{2}{ }^{-}$and chlorophyll, while the free-living PCs were largely associated with high $\mathrm{NO}_{2}{ }^{-}$concentrations.

PMEs/PDMEs in the ETSP typically contributed less than $10 \%$ of the total IPL pool from the photic zone through the core OMZ, with maximum contributions in the free-living fraction of the mesopelagic region $(\sim 20 \%)$. The distribution of the 17 molecules detected was largely the same in the particleattached fraction, but showed variability with depth in the free-living fraction (Supplementary Figure 3A). The fractional abundances of PME/PDME indicated a dominance of particleattached molecules for the entire water column, except in the mesopelagic region (Supplementary Figures 4, 5).

\section{Betaine Lipid Distribution}

Betaine lipids (BLs) DGTA, DGTS, and DGCC remained minor contributors to the total IPL pool at all depths and fraction sizes $(<10 \%$; Figure 3$)$, but were amongst the most diverse IPL classes 

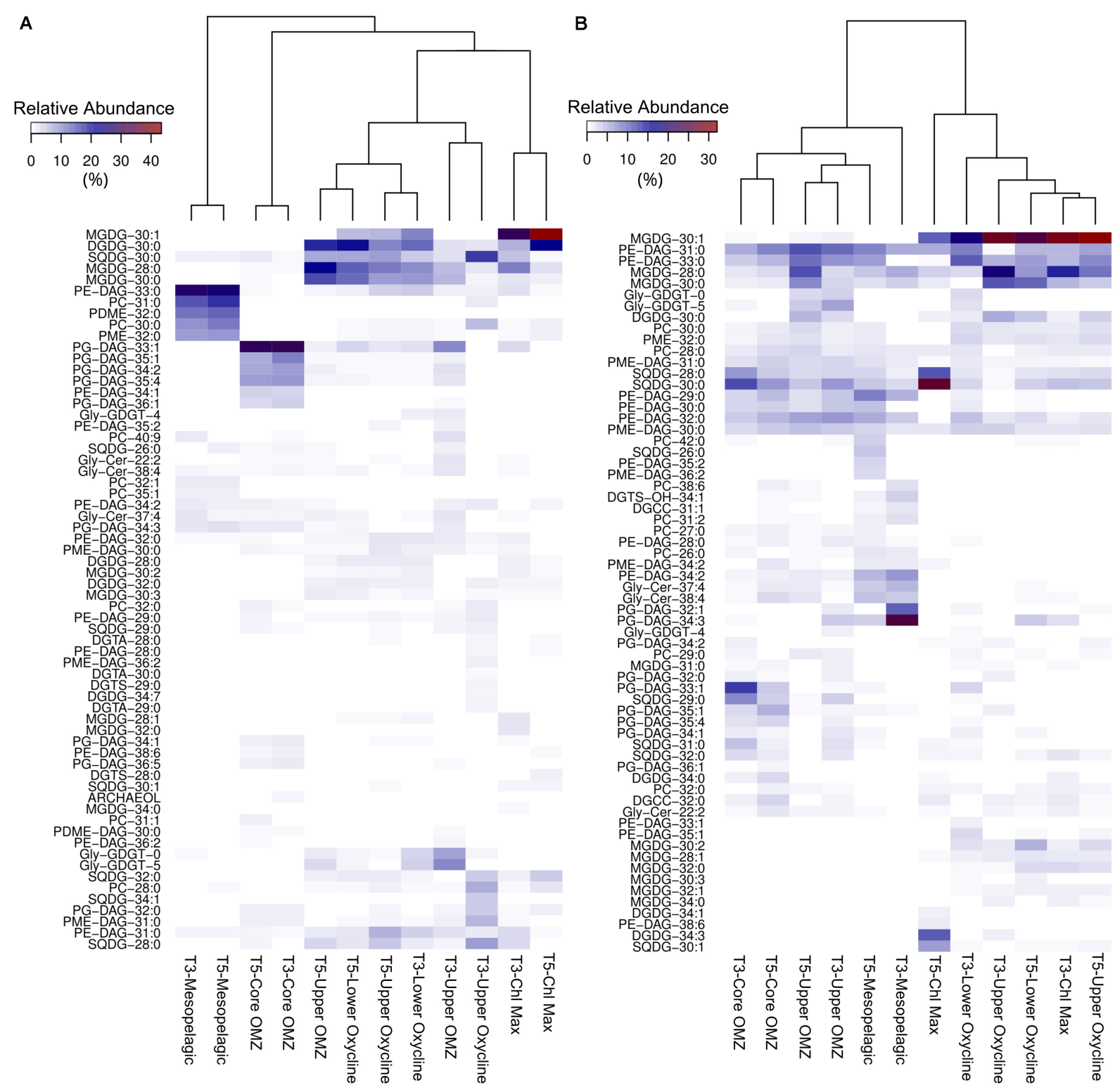

FIGURE 6 | Heatmap and cluster analysis of IPLs contributing > 5\% of the total IPL pool in at least one depth, separated by free-living fraction (A) particle-attached fraction (B).

in the ETSP, with 23, 42, and 20 unique compounds, respectively (Supplementary Figures 6A-C). Generally, BLs were associated with relatively high chlorophyll and $\mathrm{O}_{2}$ concentrations (Figure 5) and were more abundant in the particle-attached fraction, except in the upper and core OMZ (see Supplementary Figures 4, 5).

\section{Archaeal and Other Lipids}

Archaeal lipids (AR) contributed less than 5-15\% of the total IPL yield in the free-living fraction of the lower oxycline and upper OMZ (Figure 3). The most abundant intact gly-GDGTs (glycerol dialkyl glycerol tetraethers) were detected in nearly all depths amongst the free-living fraction (gly-GDGT-0 and gly-GDGT5 - also known as gly-crenarchaeol), but only between the lower oxycline and upper OMZ in the particle-attached fraction (see Supplementary Figure 3B). Ornithine lipids and sphingosine lipids (grouped as "Other"), remained minor contributors to the total IPL pool at all depths ( $<5 \%$; Figure 3$)$.

\section{DISCUSSION}

\section{Water Column Environment and IPL Abundances}

The upper $25 \mathrm{~m}$ of the water column in both stations is characterized by high chlorophyll, POC and PON, but low nutrient concentrations (Figure 2), as commonly seen in the 


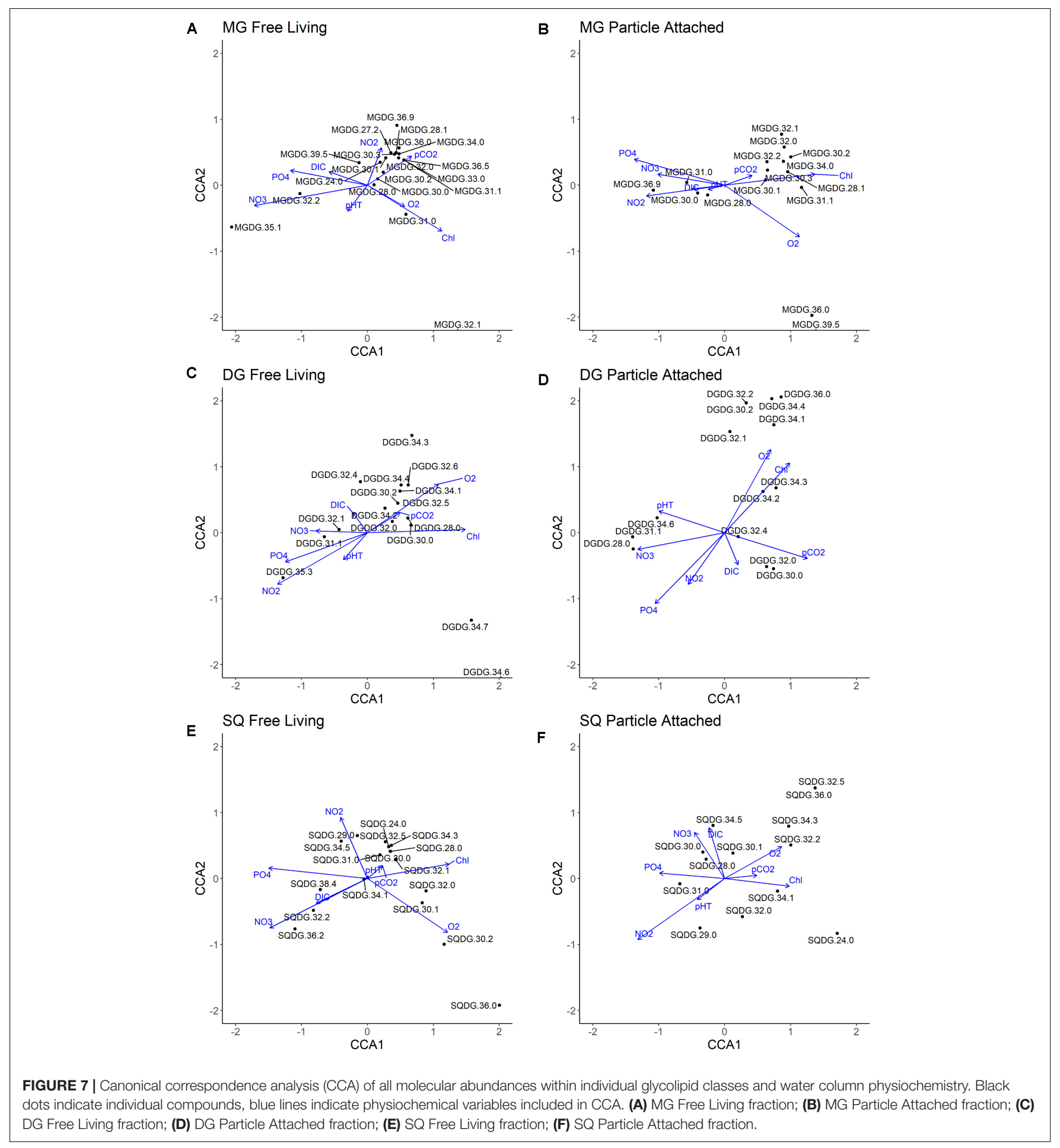

highly productive surface waters of the ETSP (Molina et al., 2007; Galán et al., 2009; Molina and Farías, 2009; Ulloa et al., 2012). At these depths, total IPL yields are also at their highest, indicative of high phytoplanktonic biomass supplying the oxycline with organic substrates. Through the oxycline, $\mathrm{PO}_{4}{ }^{3-}$ concentrations dramatically increase, reflecting high organic matter remineralization that quickly depletes the oxygen supply within 50-60 $\mathrm{m}$ from the surface. $\mathrm{NO}_{3}{ }^{-}$concentration increases in the oxycline as well, due to a high supply of remineralized $\mathrm{NH}_{4}{ }^{+}$that fuels nitrification in the lower oxycline, particularly by archaea (Molina et al., 2010; Stewart et al., 2012), also coinciding with maximal archaeal IPL yields (Figure 3). The OMZ is characterized by a secondary minimum of $\mathrm{NO}_{3}{ }^{-}$as a result of denitrification; a sharp increase in $\mathrm{NO}_{2}{ }^{-}$is characteristic for the 


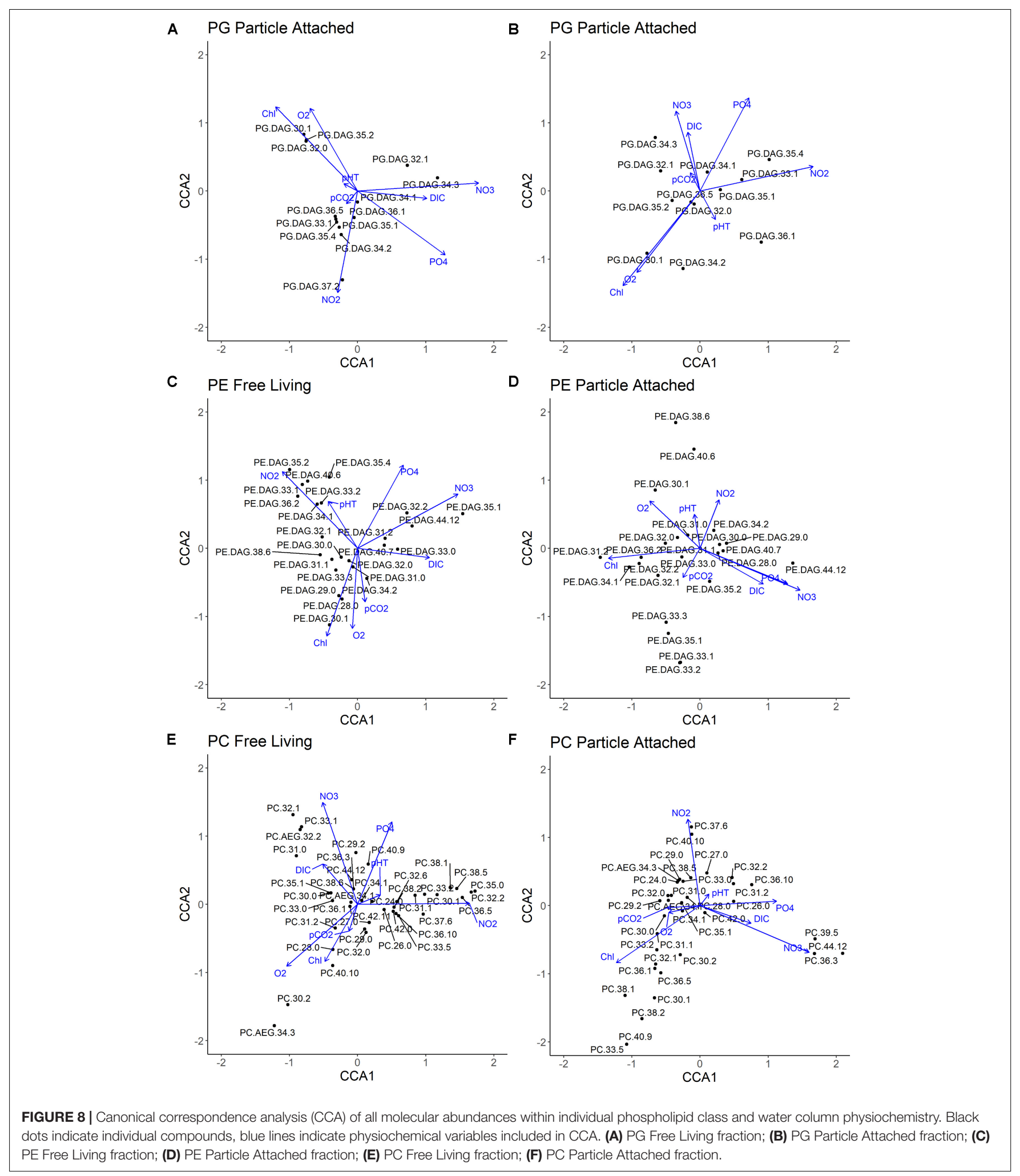

region resulting from nitrate reduction and as an intermediate of denitrification (Ulloa et al., 2012). Active expression of sulfur oxidizing/reducing bacteria have also been observed in the core OMZ (Walsh et al., 2009; Canfield et al., 2010; Ulloa et al.,
2012). Anammox bacteria are also active in this region (Galán et al., 2009; Dalsgaard et al., 2012; Stewart et al., 2012) and may contribute significantly to total nitrogen loss (Kuypers et al., 2006; Thamdrup et al., 2006; Lam and Kuypers, 2011) in the form of $\mathrm{N}_{2}$. 


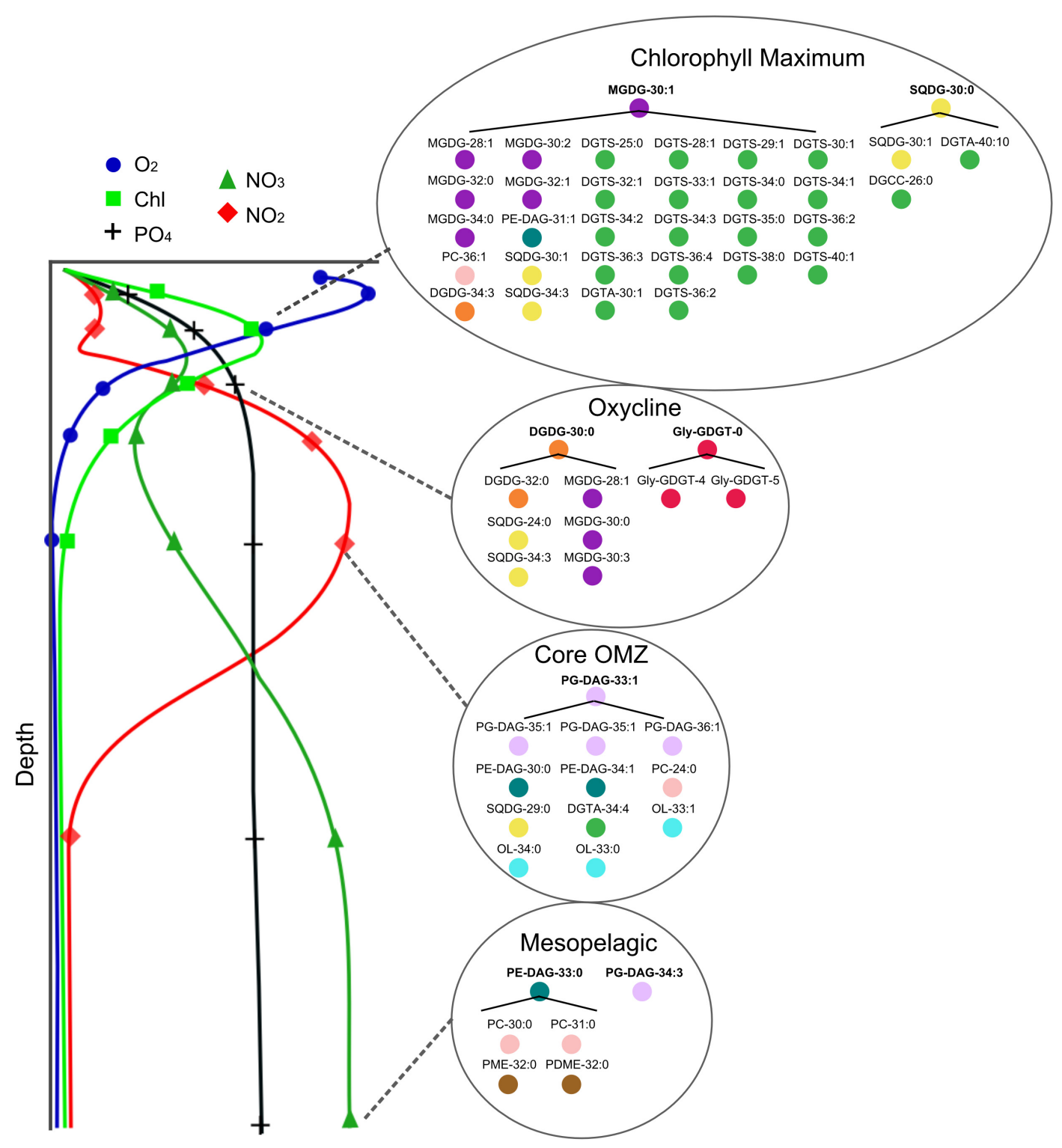

FIGURE 9 | Schematic of IPL clusters most diagnostic of the geochemical environment in either size fraction along idealized profiles of water column chemistry in this area of the ETSP. Molecules in bold are the most abundant compounds at a given depth, while other molecules under brackets indicate those with a strong correlation $\left(R^{2}>0.65\right.$ and $\left.p<0.001\right)$ to molecules in bold.

Thus, we expect IPLs along the chemocline to be reflective of a mixture of photoautotrophs, aerobic heterotrophs, and nitrifying microbes, while IPLs in the oxygen minimum zone are likely produced by nitrate reducers, denitrifiers, anaerobic ammonia oxidizers (anammox), and potentially sulfur oxidizing/reducing bacteria, among others.

\section{Potential Sources of IPLs MGDG (Monoglycosyldiacylglycerol)}

MGDGs are the dominant constituents of chloroplast thylakoid membranes in both eukaryotic and bacterial photoautotrophs (Harwood, 1998; Wada and Murata,
1998). Indeed, in surface waters of other oxygen-depleted systems these lipids have been attributed to prochlorophytes as well as to algal sources (Van Mooy and Fredricks, 2010; Schubotz et al., 2018). Surface production in the ETSP is thought to be dominated principally by diatoms, although with a significant contribution of chlorophytes, and an increasing contribution of the cyanobacteria with depth (Franz et al., 2012).

High abundances of diatoms in this region (Franz et al., 2012) suggest that particle-attached MGDGs associated with high chlorophyll concentration (Figure 7B) are derived from predominantly algal sources. An especially high ratio of particle-attached to the free-living MGDGs 
(see Supplementary Figures 4C, 5C) in the near-surface samples also supports their predominantly algal origins. Their molecular structure differs, however, from the typical polyunsaturated fatty acids observed in the IPLs of eukaryotic phytoplankton (Van Mooy and Fredricks, 2010; Schubotz et al., 2018). Instead, many are comprised of monounsaturated and saturated fatty acids (the most abundant being MGDG-30:1), which are typically more common in cyanobacteria (Harwood, 1998; Wada and Murata, 1998). The same highly abundant molecule (MGDG-30:1) in the free-living fraction clusters toward moderate $\mathrm{pCO}_{2}$ and $\mathrm{NO}_{2}{ }^{-}$ and provides evidence for a distinct bacterial source for the same molecule in the photic zone, possibly attributable to high cell counts of Prochlorococcus in subsurface waters (Lavin et al., 2010; Garcia-Robledo et al., 2017; Aldunate et al., 2020).

Contrary to the typical designation of MGDGs to photoautotrophic sources, Popendorf et al. (2011) demonstrated a substantial component of heterotrophic bacteria in the synthesis of MGDG membranes in regrowth incubations. Glycolipids are also known to be synthesized by aerobic/anaerobic gram-positive bacteria (Hölzl and Dörmann, 2007). In the ETSP, CCA clustering demonstrates that most MGDGs in the free-living fraction are associated with high $\mathrm{NO}_{2}{ }^{-}$and $\mathrm{pCO}_{2}$ (Figure 7A), likely representing suboxic heterotrophic sources, as MGDGs are nearly absent in the core OMZ. Molecules that are weakly loaded on either CCA axis (e.g., MGDG-28:0), yet with increasing relative abundance at depth, may be indicative of more ubiquitous bacterial sources found across the oxycline.

\section{DGDG (Diglycosyldiacylglycerol)}

DGDGs are a significant IPL class amongst both eukaryotic and bacterial photoautotrophs (Wada and Murata, 1998; Kalisch et al., 2016). Molecules closely correlated to high chlorophyll and $\mathrm{O}_{2}$ concentrations amongst free-living DGDGs (Figures 7C,D) suggest predominantly cyanobacterial origins. Most particleattached DGDGs also demonstrate a similar correlation and are likely reflective of algal biomass. However, the most abundant DGDG (30:0) lacks correlation to chlorophyll and $\mathrm{O}_{2}$, possibly as a result of vertical export from surface to subsurface waters, or due to a heterotrophic source relying on particleattached organic substrates persisting through suboxic to anoxic (upper OMZ) waters.

Other DGDGs are unique to OMZ (i.e., $35: 3$ and 32:0) and mesopelagic (i.e., 32:4 and 31:1) waters (Supplementary Figure 1B), and potentially indicate previously unrecognized bacterial sources. A number of bacteria have demonstrated capability of producing DGDGs, such as lactic acid bacteria (Calvano et al., 2011), Bacillus and Staphylococcus gram positive bacteria (Shaw, 1974; Hölzl and Dörmann, 2007), and heterotrophic actinobacteria/proteobacteria (Yao et al., 2016). Relative abundances of 16s rRNA gene clone sequences indicate a prevalence of proteobacteria and the appearance of actinobacteria in the core OMZ of the ESTP (Stevens and Ulloa, 2008). Notably, the fractional abundance of free-living DGDGs is considerably higher at almost all depths (Supplementary Figures 4C, 5C) further supporting their potential synthesis from non-algal sources.
As observed in other glycolipids, the canonical photoautotrophic membrane IPLs detected in the ETSP are dominated by fatty acids most common to cyanobacteria (Volkman et al., 1989; Siegenthaler, 1998; Wada and Murata, 1998). Other water column environments have shown a greater proportion of polyunsaturated lipids in the photic zone such as in the eastern subtropical Pacific (Van Mooy and Fredricks, 2010), the eastern tropical north Pacific (Schubotz et al., 2018), the Black Sea (Schubotz et al., 2009), and the Cariaco Basin (Wakeham et al., 2012). However, Breteler et al. (2005) observed significant shifts toward saturated fatty acids in diatoms as the result of nutrient limitation (both $\mathrm{N}$ and $\mathrm{P}$ ). The $\mathrm{N}: \mathrm{P}$ ratios are low in the chlorophyll maximum and upper oxycline $(<16$; Supplementary Table 2), potentially indicating an impact of $\mathrm{N}$-limitation/stress on the synthesis of glycolipid fatty acids (including both MGDGs and DGDGs).

\section{SQDG (Sulfoquinovosyldiacylglycerol)}

SQDGs, a common glycolipid class in the surface ocean, are found in thylakoid/chloroplast membranes (Siegenthaler, 1998; Wada and Murata, 1998) and are generally thought to reflect the presence of photoautotrophs in the water column (Van Mooy et al., 2006; Popendorf et al., 2011). These lipids constitute a significant proportion of cyanobacterial, diatom, brown and green algal chloroplast membranes (Harwood, 1998). However, in the ETSP, the relative contribution of SQDGs in the photic zone is larger in the free-living fraction than the particle-attached fraction (see Supplementary Figures 4C, 5C), suggesting a likely higher contribution of cyanobacteria than algae to this pool of IPLs.

CCA analyses in the free-living fraction are consistent with abundant SQDG molecules attributed to cyanobacteria (Figure 7E); however, many of these same molecules have a negative correlation to chlorophyll in the particle-attached fraction (Figure 7F). Furthermore, SQDG molecules in the core OMZ and mesopelagic region are largely dominated by the same molecules as the surface. Export of surface-derived photoautotrophic membranes may explain this distribution and a negative correlation to chlorophyll concentration. The negative correlation to chlorophyll may also be explained by the contribution of low-light adapted Prochlorococcus in the chemocline and upper OMZ of the ETSP where chlorophyll concentrations drop rapidly (Garcia-Robledo et al., 2017; Aldunate et al., 2020).

SQDGs associated with high $\mathrm{NO}_{2}{ }^{-}$or $\mathrm{NO}_{3}{ }^{-}$ concentrations potentially suggest previously undescribed non-photoautotrophic sources in marine settings. Indeed, the genes involved in lipid biosynthesis discovered in Rhodobacter (Rba.) sphaeroides and other proteobacteria include the $s q d$ gene for the synthesis of SQDGs (Tamot and Benning, 2009). The strong correlation of SQDG-29:0 for instance, with $\mathrm{NO}_{2}{ }^{-}$ in both size fractions (Figures 7E,F) suggests no strong preference for a free-living or particle-associated life modes. In addition, some SQDGs are unique to the mesopelagic region, which indicates that their distribution is related to the distinct geochemical environment and not simply a result of particle export from waters above. 


\section{PG (Phosphatidylglycerol)}

PGs are phospholipids with highly diverse biological origins, including nitrifying (Goldfine and Hagen, 1968), green sulfur (Barridge and Shively, 1968; Imhoff, 1995), Pelagibacter ubique type Proteobacteria (Van Mooy et al., 2009), sulfate reducing bacteria (Rütters et al., 2001), and methanotrophic bacteria (Makula, 1978; Fang et al., 2000). PGs are also an essential component of thylakoid membranes in both algal and bacterial photoautotrophs (Gombos et al., 2002; Sato et al., 2000). The CCA clustering in both size fractions suggest that few PGs are likely derived from photoautotrophs in the ETSP. These are limited to PG-30:1, 32:0, and 35:2 in the free-living fraction and PG-30:1, 34:2, and potentially 36:1 in the particle-attached. A predominantly non-algal source is also supported by a higher fractional abundance of PGs in the free-living fraction (see Supplementary Figures 4C, 5C).

PG relative abundances broadly increase with depth and have been mostly attributed to bacterial sources in similar environments influenced by the presence of an OMZ (Van Mooy and Fredricks, 2010; Schubotz et al., 2018). Most PGs are associated with higher $\mathrm{NO}_{2}^{-}$and $\mathrm{pCO}_{2}$ concentrations in the free-living fraction (Figure $\mathbf{8 A}$ ), suggesting a core $\mathrm{OMZ}$ origin. However, the distribution of PG-34:2, 36:1, and 36:5 in the particle-attached fraction all cluster along distinct geochemical environments than in the free-living fraction (Figures $\mathbf{8 A}, \mathbf{B}$ ). This size partitioning may be related to a tendency for anaerobic heterotrophs to rely on organic substrates supplied via particle export (Karl et al., 1984; Arístegui et al., 2009), while autotrophic bacteria capable of fixing inorganic carbon may be more common in a free-living life mode. The $16 \mathrm{~S}$ transcript abundances encoding enzymes for key denitrification steps have been measured to be 28 -fold higher in particle-associated fractions, while anammox transcript abundances indicate a 15fold enrichment in free-living fractions (Ganesh et al., 2015). While bacteriohopanepolyols (BHPs) associated with anammox bacteria in this OMZ system have been shown to be slightly more abundant in the particle-associated fraction, they are thought to be produced in the free-living fraction and accumulated in the larger fraction via the process of particle aggregation (Matys et al., 2017). Thus, non-ladderane phospholipids produced by anammox bacteria (Rattray et al., 2009) are a possible origin of free-living PGs in the OMZ. Indeed, the relative contribution of PGs are highest in the core OMZ (Figure 3), where expression of anammox transcripts are highest (Galán et al., 2009; Ulloa et al., 2012). PG-34:1 is also present at most depths and both size fractions (see Supplementary Figure 2B), and shows little correlation to any highly distinct geochemical environment (Figures 8A,B). This result suggests broadly ubiquitous origins, such as the ubiquitous heterotrophic Pelagibacter ubique (part of the SAR11 clade), shown to exclusively synthesize PG and PE membrane lipids (Van Mooy et al., 2009).

\section{PE (Phosphatidylethanolamine)}

PEs are commonly found in bacterial membranes from organisms with diverse metabolisms that include: nitrifying/denitrifying bacteria (Goldfine and Hagen, 1968), methanotrophic (Makula, 1978; Fang et al., 2000), sulfur oxidizing (Barridge and Shively, 1968; Imhoff, 1995), and $\mathrm{SO}_{4}$ reducing bacteria (Rütters et al., 2001; Sturt et al., 2004). They have been largely attributed to heterotrophic bacteria in similar environments (Van Mooy and Fredricks, 2010; Schubotz et al., 2018). They can be a minor component of algal membranes as well (Dembitsky, 1996).

The most abundant PEs in both size fractions (e.g., PE31:0, 33:0) lack strong correlations to chlorophyll and $\mathrm{O}_{2}$ (Figures 8C,D), indicating minimal photoautotrophic sources in the photic zone. We interpret the occurrence of PEs in the chlorophyll maximum and oxycline as largely derived from ubiquitous aerobic heterotrophs. This is supported by their predominantly monounsaturated and saturated core structures more commonly found in bacterial fatty acids (Harwood, 1998; Wada and Murata, 1998), a lack of strong correlation to physiochemical environment, and their high abundance in Pelagibacter ubique (Van Mooy et al., 2009).

PE-32:2, PE-35:1, and PE-44:12 are associated with high $\mathrm{NO}_{3}{ }^{-}$concentrations in the free-living fraction (Figure 8C), while constrained to the lower oxycline and mesopelagic (Supplementary Figure 2C), suggesting nitrifying bacterial sources. This observation is supported by a prevalence of nitrifiers in free-living life modes in this area (Ganesh et al., 2014, 2015).

PEs that are positively correlated with $\mathrm{NO}_{2}{ }^{-}$concentrations (33:1, 33:2, 34:1, 35:4, 35:2, and 36:2; Figure 8C) have many potential sources in the highly diverse core OMZ including denitrifying, nitrate reducing, or sulfur cycling bacteria (Canfield et al., 2010; Ulloa et al., 2012). Non-ladderane PEs are also produced by anammox bacteria (Rattray et al., 2009), and may be contributing to these free-living IPLs unique to the core OMZ. These multiple biological sources are also reflected in the considerably diverse distribution of PEs found in the core OMZ (Supplementary Figure 2C).

Some clarity in the potential sources of these core OMZ PEs may be illuminated by differences in their physicochemical correlations in the two size fractions. For instance, several of the free-living PEs (33:1, 33:2, and 35:2) in high $\mathrm{NO}_{2}{ }^{-}$ environments are negatively correlated to $\mathrm{NO}_{2}{ }^{-}$in the particleattached fraction (Figure 8D). These differences could be an indication of largely heterotrophic bacteria relying on organic substrates in the particle-attached fraction, and a prevalence of autotrophic bacteria in the free-living fraction capable of fixing dissolved inorganic carbon. These observations demonstrate the importance of size-fractionated analyses to differentiate between microbial sources of different life modes.

\section{PC (Phosphatidylcholine)}

In marine settings, PCs are predominantly attributed to eukaryotic sources (Van Mooy et al., 2006; Van Mooy and Fredricks, 2010), or heterotrophic bacteria (Popendorf et al., 2011). Photoheterotrophic bacteria have also been shown to produce PCs (Van Mooy et al., 2006); however, since ornithine lipids, a common membrane lipid of photoheterotrophs (Benning, 1998), were hardly detected in our samples, such a source is rather unlikely. 
The correlations of PC-30:0, the most abundant PC in the photic zone (Supplementary Figure 2A), with water column conditions (Figures $\mathbf{8 E}, \mathbf{F}$ ) likely indicate aerobic heterotrophic sources in the free-living fraction, and algal sources in the particle-attached. Clusters of PC molecules in the particle-attached fraction correlated to high chlorophyll vs. moderate concentrations of both chlorophyll and $\mathrm{NO}_{2}{ }^{-}$, may differentiate between photoautotrophs in near surface and intermediate waters.

PCs in the free-living fraction show a large diversity that correlates to core OMZ water column chemistry (Figure 8E), suggesting predominantly anaerobic sources of these molecules. Considering the increased diversity and unique distribution of these PC molecules in core OMZ waters, it is unlikely that they represent exported material from photoautotrophs in the surface. Rather, there seems to be a considerable contribution of in situ production in the core OMZ. For instance, the genes relevant to synthesis of PC have also been found in homologs of numerous chemoheterotrophic and chemoautotrophic bacteria (Sohlenkamp et al., 2003). Furthermore, in the mesopelagic region, a notable contribution of PC-31:0 correlating with $\mathrm{NO}_{3}{ }^{-}$, and to a lesser extent $\mathrm{O}_{2}$ (Figure 8E), suggests possible deepwater nitrification.

While the observation of non-photoautotrophic sources of PCs in OMZ systems is novel, we can only speculate at this time as to which of the many organisms present in the core OMZ could be responsible for these lipids. A size-fractionated analysis that combines transcriptomic and lipidomic measurements may be necessary to determine more specific biological sources.

\section{PME/PDME [Phosphatidyl(di)methylethanolamine]}

PME/PDME have been loosely attributed to bacteria along chemoclines in marine environments (Schubotz et al., 2009; Wakeham et al., 2012), as their synthesis is predominantly found amongst Proteobacteria (Oliver and Colwell, 1973; Goldfine, 1984). The particle-attached fraction shows the majority of molecules (PME-32:0, PME-33:1, PDME-31:1, PDME-33:2, PDME-35:1, and PDME-36:2) clustering between $\mathrm{PO}_{4}{ }^{3-}$ and $\mathrm{pCO}_{2}$, and negatively correlated to $\mathrm{O}_{2}$, which suggests predominantly heterotrophic sources (Supplementary Figure 6B). Several compounds (PME-30:0, PME-31:0, and PDME-29:4) also cluster between $\mathrm{O}_{2}$ and $\mathrm{pH}$, possibly indicating differentiation between aerobic and anaerobic heterotrophs. The free-living fraction shows a clustering of these molecules along $\mathrm{pCO}_{2}$ and chlorophyll concentrations, possibly suggesting a cyanobacterial source (Supplementary Figure 6A). Furthermore, the greater diversity seen in core OMZ waters, in addition of their positive correlation with $\mathrm{NO}_{2}{ }^{-}$, are again suggestive of denitrifying or nitrate reducing bacteria. Possible candidates of nitrifying bacterial lipids include PME-35:4 and PDME-33:1.

\section{Betaine Lipids}

Most common forms of betaine lipids in surface marine environments (DGTS; diacylglyceryl trimethylhomoserine, DGTA; diacylglyceryl hydroxymethyl-trimethyl-b-alanine, and DGCC; diacylglyceryl carboxyhydroxymethylcholine; Schubotz et al., 2009, 2018; Van Mooy and Fredricks, 2010; Wakeham et al., 2012) were found in low relative abundance compared to glyco- and phospholipids (Figure 3). While betaine lipids are most common to eukaryotic phytoplankton (Kato et al., 1996), it has also been suggested that their origins may be considerably more diverse than previously assumed (Schubotz et al., 2018). In the photic zone, it remains likely that they are synthesized by photosynthetic eukaryotes, but their diversity and unique distributions (Supplementary Figures 7A-C), and increased presence in the free-living fraction in the upper and core OMZ (Supplementary Figures 4C, 5C) suggest additional, previously non-recognized microbial sources.

While lipid remodeling in response to phosphorus limitation (Benning et al., 1995) in oligotrophic regions has been well described (Van Mooy et al., 2009; Carini et al., 2015; Sebastián et al., 2016), only the restructuring of fatty acids in glycolipids has been observed under N-limitation (Breteler et al., 2005). The strikingly low abundance of betaine lipids in the photic zone of the ETSP suggests that further investigation in the potential lipid substitution of glyco- or phospolipids under N-depleted conditions is warranted.

\section{Archaeal Lipids}

Archaeal lipids have been shown to be abundant along the oxycline of similar marine environments (Schouten et al., 2012; Xie et al., 2014; Schubotz et al., 2018) where ammonia oxidizing crenarchaeota supply the water column with oxidized nitrogen species (Francis et al., 2007). Indeed, in the ETSP, ammonia oxidizing archaea are considerably more abundant than nitrifying bacteria (Bouskill et al., 2012). We succeeded in measuring 3 of the suspected intact glycosidic-GDGTs in greatest abundance along the oxycline and upper OMZ, demonstrating a present albeit underrepresented archaeal contribution to the total IPL pool (Figure 3). While the most common glycosidic-GDGTs (GDGT-0 and GDGT-5 or crenarchaeol; Pitcher et al., 2011) were detected (Supplementary Figure 3B), our analyses likely show limited representation of archaeal lipids, possibly a result of vastly different ionization efficiencies of this IPL class and relatively poor detection limits with the available volumes of seawater.

\section{Utility of IPLs as Biomarkers for in situ Planktonic/Microbial Communities}

The interpretation of IPL distributions in the environment is limited by factors that complicate the determination of the exact biological source(s) of a given molecule. The varying lability of individual lipids, in addition to varying residence times of IPLs driven by particle fluxes, influence the relative contribution of IPLs potentially exported to underlying depths. While IPLs are often considered to hydrolyze quickly after cell death (White et al., 1979; Petersen et al., 1991), it has been demonstrated that certain compounds can remain intact for weeks to months (Harvey et al., 1986; Brandsma, 2011; Logemann et al., 2011). Slower degradation rates were found to be most pronounced in SQDGs (Brandsma, 2011) suggesting a higher potential of this lipid class to survive export to the deep ocean. While a large percentage of SQDGs from the core OMZ and mesopelagic do not appear in the photic zone, molecules that are abundant throughout the water column (such as SQDG-30:0 and 28:0) may 
contribute $10-20 \%$ of the particle-attached total IPL yield in the OMZ core and $\sim 10 \%$ in the mesopelagic, suggesting the potential for a significant contribution of exported material.

Statistical analyses such as CCAs that include IPLs concentrations and physiochemical conditions allow us to refine interpretations of biogeochemical trends beyond the relative abundances of IPL classes. A CCA of all detected IPL abundances under a range of geochemical conditions (Figure 4) indicates that each geochemical environment through the water column exhibits a statistically distinct total IPL distribution. There are several characteristic clusters of IPLs in surface waters, along the oxycline, and OMZ waters that correlate with the distribution of key nutrient species (i.e., $\mathrm{NO}_{3}{ }^{-}, \mathrm{PO}_{4}{ }^{3-}$, and $\mathrm{NO}_{2}{ }^{-}$), in addition to chlorophyll and $\mathrm{O}_{2}$. This indicates that despite the overlap in some IPLs detected between geochemical environments, their overall distributions suggest that IPL export is limited and does not significantly hinder their utility as biomarkers of in situ planktonic/microbial biomass in the OMZ of the ETSP.

Our results indicate that the specificity of determining IPL sources can be improved upon by incorporating sizefractionated analyses. Despite some similarities between the free-living and particle-attached size fractions of POM, there is significant variability within size-fractionated IPL distributions as well, illuminating potential differences between microbial life modes. Our CCA analyses indicate that many phospholipids abundant in both size fractions correlate strongly with different physicochemical conditions, supporting the observation of distinct transcriptomic abundances between particle-attached and free-living life modes (Wright et al., 2012; Ganesh et al., 2014, 2015). Free-living microbes are exposed directly to biogeochemical variations, whereas particle-attached organisms may reflect redox-driven niche partitioning (Wright et al., 2012). Furthermore, particles sinking to the core OMZ taxonomically reflect those of particles in the oxic zone, potentially serving as a mechanism for the transport of bacteria to OMZ depths (Ganesh et al., 2014). Size-fractionated IPL analyses thus provide additional information in determining the biological origins of molecules common to multiple biological sources.

Total IPL assays are also constrained by limits in our knowledge of the full extent of IPL diversity in the marine environment and the exact biological origins of individual compounds. While we have shown that there are differences in IPL distributions due to differing life modes at a given depth, there are IPLs consistently dominant in specific geochemical environments (see Figure 6). To identify molecules that are particularly diagnostic of the geochemical environment we selected the most abundant molecules present in each environment and calculated clusters of highly correlated molecules $\left(R^{2}>0.65\right.$ and $p<0.001$; Figure 9). These clusters summarize much of the unique IPL distributions between water column conditions found in the ETSP. The oxygenated chlorophyll maximum is dominated by a number of glycolipids and a high diversity albeit lower concentration of betaine lipids, indicative of IPLs largely associated with photoautotrophs. The oxycline sees a shift to distinct glycolipid assemblages potentially due to an increased contribution in cyanobacterial and heterotrophic bacterial sources. In addition, the oxycline sees increased contribution of ammonia oxidizing archaeal GDGTs. The core OMZ is dominated by phospholipids reflecting both heterotrophic and chemoautotrophic bacteria. Finally, the oxygenated mesopelagic denotes a unique distribution of predominantly phospholipids associated with aerobic heterotrophs.

\section{Contribution of Microbial Biomass to Suspended Organic Matter}

Total IPL concentrations in the ETSP dramatically decrease with depth (Figure 3), as also seen in similar systems around the world (Van Mooy and Fredricks, 2010; Schubotz et al., 2018). However, the contribution of IPLs to total organic carbon stocks is larger in the chemocline than in the chlorophyll maximum, suggesting a potentially significant contribution of predominantly microbial biomass that characterizes these subsurface environments. Also, the fractional abundance of IPLs from the free-living fraction tends to increase with depth, indicating a greater contribution of free-living organisms and a reduced contribution of exported or particle-associated biomass.

The fractional abundances of IPL classes with depth indicates which classes are dominant amongst free-living or particleattached communities. At most depths, DGs, PGs, and ARs are more abundant in the free-living fraction. Conversely, DGCCs, PEs, and PME/PDMEs are at most depths higher in the particleattached fraction. The biological sources of these IPLs present at multiple depths in the water column may be disentangled by their associated life modes. Namely, the prevalence of denitrifying/nitrate reducing bacteria and the SAR324 cluster (with genomic potential for chemolithoautotrophy via sulfur or methane oxidation; Swan et al., 2011) in particle-attached niches, and nitrifying archaea/anammox bacteria in free-living niches (Wright et al., 2012; Ganesh et al., 2015).

If we assume that the total IPL concentrations at each respective depth are proportional to the concentration of living biomass, we can roughly compare the microbial carbon standing stocks of the OMZ to the photic zone. This simple exercise includes a depth-averaged IPL concentration for the photic zone (defined as the upper 55 and $60 \mathrm{~m}$ in the nearshore and offshore stations, respectively), and a depth averaged IPL concentration for the $\mathrm{OMZ}$ using the values from the upper and core $\mathrm{OMZ}$ (i.e., 55-500 $\mathrm{m}$ and 60-500 $\mathrm{m}$ in the nearshore and offshore stations, respectively). To account for the contribution of potentially more refractory IPLs exported in the particle-attached fraction, we assume that only 75\% of the IPL pool is produced in situ (a conservative estimate based on the IPL distributions discussed above). We can then calculate the microbial biomass in any given water parcel of the photic zone and the OMZ. This exercise shows that the total IPLs stock (and thus microbial carbon standing stock) in OMZ waters is $10-20 \%$ greater than that in the photic zone, with a greater relative contribution of OMZ carbon stocks in the nearshore station. These first order calculations are subject to large uncertainties (e.g., vertical variability of biomass, relative lability of compounds, seasonality) 
and are meant to be semi-quantitative at most. However, they suggest a potential for microbially derived biomass to account for a significant fraction of the total organic carbon in this OMZ system. This microbial contribution to organic carbon production may indicate a greater contribution of microbes to organic carbon export, as recently observed in Arabian Sea sediments (Lengger et al., 2020).

\section{CONCLUSION}

Size-fractionated IPL distributions in suspended organic matter from the ETSP off northern Chile indicate that particle-attached and free-living microbial biomass can differ significantly within the same geochemical environment, suggesting that sizefractionated IPL analysis provides improved utility in exploring the diversity of IPLs in the environment and determining their biological origins. Phospholipid distributions and CCA with physiochemical conditions across the oxycline and core OMZ provide evidence that autotrophic microbes may be more abundant in free-living modes, and heterotrophic biomass in particle-attached modes. In addition, these size-specific analyses may aid in identifying IPLs that may not reflect living biomass, but potentially export efficiency based on their relative lability, significant abundance at all depths and both size fractions, and the lack of significant correlation to a distinct geochemical environment. We expect potentially exported IPLs to be largely limited to few glycolipids in the particle-attached fraction and to not significantly convolute biomass interpretations in the OMZ of the ETSP.

The relative contribution of IPLs in the free-living fraction is larger than in the particle-associated fraction in OMZ and mesopelagic waters, suggesting a greater relative contribution of submicron organics to standing carbon stocks in the deep ocean. Furthermore, a first-order approximation on the total IPL standing stocks between the oxic part of the photic zone and $\mathrm{OMZ}$ waters indicates that microbial biomass in the latter may rival that of the former. This warrants further investigation into the common assumption that biomass production in the photic zone is the main source of organic carbon export to the deep ocean. Our results suggest that dark carbon fixation in OMZ waters could contribute to carbon export to the deep ocean.

The distribution of IPLs in the ETSP system of northern Chile exhibits some unique features compared to the eastern subtropical south Pacific and tropical North Pacific. Namely, the low abundance of betaine/aminolipids, a common IPL found in eukaryotic photoautotrophs, possibly suggests a physiological response to nitrogen limitation. Furthermore, the low abundance of polyunsaturated fatty acids in the photic zone, which are most abundant in algal IPLs, suggest that the commonly evoked dichotomy between bacterial and eukaryotic fatty acids may vary in distinct environments. Finally, the appearance of glycolipids and betaine lipids unique to the OMZ or mesopelagic suggest previously undescribed microbial sources contributing significantly to the total IPL pool.

\section{DATA AVAILABILITY STATEMENT}

The data have been published on PANGAEA pending a DOI but will be available here: https://doi.org/10.1594/PANGAEA. 921190.

\section{AUTHOR CONTRIBUTIONS}

SC, JS, CV, and PD designed the study. CV, PD, and JS funded the research and the LowpHOx-2 cruise. SC carried out the sampling, sample preparation, developed the HPLC-MS analytical methods with assistance from ND and JS, performed the biomarker and elemental analysis, and processed the data. $\mathrm{CH}-\mathrm{C}$ assisted with statistical analyses. SC and JS interpreted the results and wrote the manuscript with input from all co-authors. All authors contributed to the article and approved the submitted version.

\section{FUNDING}

This study was funded by CONICYT-Chile FONDECYT Grant 1170065 (CARbon Cycling and Physiological Traits in Phytoplankton Functional Groups under low pH/low OXygen conditions, CARpHOX) and by CONICYT-Chile National Competition for ship time (AUB 170002). Partial funding was provided by the Millennium Institute of Oceanography (IMO). SC and JS acknowledge financial support from the Department of Geological Sciences and INSTAAR at the University of Colorado Boulder (CU Boulder). The workshop was funded by the Deutsche Forschungsgemeinschaft (DFG, German Research Foundation) project number: 422798570.

\section{ACKNOWLEDGMENTS}

We thank the captain and crew of the AGS-61 Cabo de Hornos, the chief scientist of the LowpHOx-2 cruise, Dr. Wolfgang Schneider (UdeC), in addition to personnel from the Millennium Institute of Oceanography (IMO) and the Laboratory of Aquatic Ecosystem Functioning at the University of Concepción for their assistance during the LowpHOx2 cruise. We are particularly grateful to P. Contreras and Nicole Castillo (UdeC), K. Rempfert (CU Boulder), and B. Davidheiser-Kroll (CU Boulder) for their assistance with cruise logistics, IPL, and elemental analyses, respectively. JS thanks the Hanse-Wissenschaftskolleg Delmenhorst, Germany, for sponsoring the "Marine Organic Biogeochemistry" workshop in April 2019. We thank the associate editor and two reviewers for comments that improved the final version of the manuscript.

\section{SUPPLEMENTARY MATERIAL}

The Supplementary Material for this article can be found online at: https://www.frontiersin.org/articles/10.3389/fmars.2020. 540643/full\#supplementary-material 


\section{REFERENCES}

Aldunate, M., Henríquez-Castillo, C., Ji, Q., Lueders-Dumont, J., Mulholland, M. R., Ward, B. B., et al. (2020). Nitrogen assimilation in picocyanobacteria inhabiting the oxygen-deficient waters of the eastern tropical North and South Pacific. Limnol. Oceanogr. 65, 437-453. doi: 10.1002/lno.11315

Arístegui, J., Gasol, J. M., Duarte, C. M., and Herndld, G. J. (2009). Microbial oceanography of the dark ocean's pelagic realm. Limnol. and Oceanogr. 54, 1501-1529. doi: 10.4319/lo.2009.54.5.1501

Arrigo, K. R. (2005). Marine microorganisms and global nutrient cycles. Nature 437, 349-355. doi: 10.1038/nature04159

Azam, F. (1998). Microbial control of oceanic carbon flux: the plot thickens. Science 280, 694-696. doi: 10.1126/science.280.5364.694

Azam, F., Fenchel, T., Field, J. G., Gray, J. S., Meyer-Reil, L. A., and Thingstad, F. (1983). The ecological role of water-column microbes in the sea. Mar. Ecol. Prog. Ser. 10, 257-263. doi: 10.3354/meps010257

Barridge, J. K., and Shively, J. M. (1968). Phospholipids of the Thiobacilli. J. Bacteriol. 95, 2182-2185. doi: 10.1128/jb.95.6.2182-21 85.1968

Benning, C. (1998). "Membrane lipids in anoxygenic photosynthetic bacteria," in Lipids in Photosynthesis: Structure, Function and Genetics, eds P.-A. Siegenthaler and N. Murata (Dordrecht: Springer), 83-101. doi: 10.1007/0-306-48087-5_5

Benning, C., Huang, Z. H., and Gage, D. A. (1995). Accumulation of a novel glycolipid and a betaine lipid in cells of Rhodobacter sphaeroides grown under phosphate limitation. Arch. Biochem. Biophys. 317, 103-111. doi: 10.1006/abbi. 1995.1141

Bligh, E. G., and Dyer, W. J. (1959). A rapid method of total lipid extraction and purification. Cana. J. Biochem. Physiol. 37, 911-917. doi: 10.1139/ o59-099

Boumann, H. A., Hopmans, E. C., Van De Leemput, I., Op den Camp, H. J., Van De Vossenberg, J., Strous, M., et al. (2006). Ladderane phospholipids in anammox bacteria comprise phosphocholine and phosphoethanolamine headgroups. FEMS Microbiol. Lett. 258, 297-304. doi: 10.1111/j.1574-6968. 2006.00233.x

Bouskill, N. J., Eveillard, D., Chien, D., Jayakumar, A., and Ward, B. B. (2012). Environmental factors determining ammonia-oxidizing organism distribution and diversity in marine environments. Environ. Microbiol. 14, 714-729. doi: 10.1111/j.1462-2920.2011.02623.x

Brandsma, J. (2011). The Origin and Fate of Intact Polar Lipids in the Marine Environment, Vol. 5. Utrecht: Utrecht university.

Brandsma, J., Hopmans, E. C., Brussaard, C. P., Witte, H. J., Schouten, S., and Sinninghe Damsté, J. S. (2012). Spatial distribution of intact polar lipids in North Sea surface waters: relationship with environmental conditions and microbial community composition. Limnol. Oceanogr. 57, 959-973. doi: 10. 4319/lo.2012.57.4.0959

Breteler, W. K., Schogt, N., and Rampen, S. (2005). Effect of diatom nutrient limitation on copepod development: role of essential lipids. Mar. Ecol. Prog. Ser. 291, 125-133. doi: 10.3354/meps291125

Calvano, C. D., Zambonin, C. G., and Palmisano, F. (2011). Lipid fingerprinting of Gram-positive lactobacilli by intact cells-matrix-assisted laser desorption/ionization mass spectrometry using a proton sponge based matrix. Rapid Commun. Mass Spectrom. 25, 1757-1764. doi: 10.1002/rcm.5035

Canfield, D. E., Stewart, F. J., Thamdrup, B., De Brabandere, L., Dalsgaard, T., Delong, E. F., et al. (2010). A cryptic sulfur cycle in oxygen-minimum-zone waters off the Chilean coast. Science 330, 1375-1378. doi: 10.1126/science. 1196889

Carini, P., Van Mooy, B. A., Thrash, J. C., White, A., Zhao, Y., Campbell, E. O., et al. (2015). SAR11 lipid renovation in response to phosphate starvation. Proc. Natl. Acad. Sci. U.S.A. 112, 7767-7772. doi: 10.1073/pnas. 1505034112

Carpenter, J. H. (1965). The chesapeake bay institute technique for the winkler dissolved oxygen method. Limnol. Oceanogr. 10, 141-143. doi: 10.4319/lo.1965. 10.1.0141

Chao, A., Chiu, C. H., and Hsieh, T. C. (2012). Proposing a resolution to debates on diversity partitioning. Ecology 93, 2037-2051. doi: 10.1890/11-1817.1

Close, H. G., Shah, S. R., Ingalls, A. E., Diefendorf, A. F., Brodie, E. L., Hansman, R. L., et al. (2013). Export of submicron particulate organic matter to mesopelagic depth in an oligotrophic gyre. Proc. Natl. Acad. Sci. U.S.A. 110, 12565-12570. doi: 10.1073/pnas. 1217514110
Close, H. G., Wakeham, S. G., and Pearson, A. (2014). Lipid and 13C signatures of submicron and suspended particulate organic matter in the Eastern Tropical North Pacific: implications for the contribution of Bacteria. Deep Sea Res. Part I Oceanogr. Res. Pap. 85, 15-34. doi: 10.1016/j.dsr.2013.11.005

Czeschel, R., Stramma, L., Schwarzkopf, F. U., Giese, B. S., Funk, A., and Karstensen, J. (2011). Middepth circulation of the eastern tropical South Pacific and its link to the oxygen minimum zone. J. Geophys. Res. Oceans 116:C01015.

Dalsgaard, T., Thamdrup, B., Farías, L., and Revsbech, N. P. (2012). Anammox and denitrification in the oxygen minimum zone of the eastern South Pacific. Limnol. Oceanogr. 57, 1331-1346. doi: 10.4319/lo.2012.57.5.1331

Daneri, G., Dellarossa, V., Quiñones, R., Jacob, B., Montero, P., and Ulloa, O. (2000). Primary production and community respiration in the Humboldt Current System off Chile and associated oceanic areas. Mar. Ecol. Prog. Ser. 197, 41-49. doi: 10.3354/meps197041

De La Rocha, C. L., Nowald, N., and Passow, U. (2008). Interactions between diatom aggregates, minerals, particulate organic carbon, and dissolved organic matter: further implications for the ballast hypothesis. Global Biogeochem. Cycles 22:GB4005.

De Pol-Holz, R., Robinson, R. S., Hebbeln, D., Sigman, D. M., and Ulloa, O. (2009). Controls on sedimentary nitrogen isotopes along the Chile margin. Deep Sea Res. Part II Top. Stud. Oceanogr. 56, 1042-1054. doi: 10.1016/j.dsr2.2008.09.014

Dembitsky, V. M. (1996). Betaine ether-linked glycerolipids: chemistry and biology. Prog. Lipid Res. 35, 1-51. doi: 10.1016/0163-7827(95)00009-7

Dickson, A. G. (1990). Standard potential of the reaction: $\mathrm{AgCl}(\mathrm{s})+12 \mathrm{H} 2(\mathrm{~g})=$ $\mathrm{Ag}(\mathrm{s})+\mathrm{HCl}(\mathrm{aq})$, and and the standard acidity constant of the ion HSO4- in synthetic sea water from 273.15 to 318.15 K. J. Chem. Thermodyn. 22, 113-127. doi: 10.1016/0021-9614(90)90074-z

Dickson, A. G., Afghan, J. D., and Anderson, G. C. (2003). Reference materials for oceanic CO2 analysis: a method for the certification of total alkalinity. Mar. Chem. 80, 185-197. doi: 10.1016/s0304-4203(02)00133-0

Dickson, A. G., and Millero, F. J. (1987). A comparison of the equilibrium constants for the dissociation of carbonic acid in seawater media. Deep Sea Res. Part A Oceanogr. Res. Pap. 34, 1733-1743. doi: 10.1016/0198-0149(87)90021-5

Ducklow, H. W. (2001). Bacterioplankton, Encyclopedia of Ocean Sciences. San Diego, CA: Academic Press, 217-224.

Duret, M. T., Pachiadaki, M. G., Stewart, F. J., Sarode, N., Christaki, U., Monchy, S., et al. (2015). Size-fractionated diversity of eukaryotic microbial communities in the Eastern Tropical North Pacific oxygen minimum zone. FEMS Microbiol. Ecol. 91:fiv037.

Dyhrman, S. T., Ammerman, J. W., and Van Mooy, B. A. (2007). Microbes and the marine phosphorus cycle. Oceanography 20, 110-116. doi: 10.5670/oceanog. 2007.54

Elling, F. J., Könneke, M., Lipp, J. S., Becker, K. W., Gagen, E. J., and Hinrichs, K. U. (2014). Effects of growth phase on the membrane lipid composition of the thaumarchaeon Nitrosopumilus maritimus and their implications for archaeal lipid distributions in the marine environment. Geochim. Cosmochim. Acta 141, 579-597. doi: 10.1016/j.gca.2014.07.005

Falkowski, P. G., Fenchel, T., and Delong, E. F. (2008). The microbial engines that drive Earth's biogeochemical cycles. Science 320, 1034-1039. doi: 10.1126/ science. 1153213

Fang, J., Barcelona, M. J., and Semrau, J. D. (2000). Characterization of methanotrophic bacteria on the basis of intact phospholipid profiles. FEMS Microbiol. Lett. 189, 67-72. doi: 10.1111/j.1574-6968.2000.tb09207.x

Finkel, Z. V., Beardall, J., Flynn, K. J., Quigg, A., Rees, T. A. V., and Raven, J. A. (2010). Phytoplankton in a changing world: cell size and elemental stoichiometry. J. Plankton Res. 32, 119-137. doi: 10.1093/plankt/fbp098

Francis, C. A., Beman, J. M., and Kuypers, M. M. M. (2007). New processes and players in the nitrogen cycle: The microbial ecology of anaerobic and archaeal ammonia oxidation. ISME J. 1, 19-27. doi: 10.1038/ismej.2007.8

Franz, J., Krahmann, G., Lavik, G., Grasse, P., Dittmar, T., and Riebesell, U. (2012). Dynamics and stoichiometry of nutrients and phytoplankton in waters influenced by the oxygen minimum zone in the eastern tropical Pacific. Deep Sea Res. Part I Oceanogr. Res. Pap. 62, 20-31. doi: 10.1016/j.dsr.2011. 12.004

Fuenzalida, R., Schneider, W., Garcés-Vargas, J., Bravo, L., and Lange, C. (2009). Vertical and horizontal extension of the oxygen minimum zone in the eastern South Pacific Ocean. Deep Sea Res. Part II Top. Stud. Oceanogr. 56, 992-1003. doi: 10.1016/j.dsr2.2008.11.001 
Galán, A., Molina, V., Thamdrup, B., Woebken, D., Lavik, G., Kuypers, M. M., et al. (2009). Anammox bacteria and the anaerobic oxidation of ammonium in the oxygen minimum zone off northern Chile. Deep Sea Res. Part II Top. Stud. Oceanogr. 56, 1021-1031. doi: 10.1016/j.dsr2.2008.09.016

Ganesh, S., Bristow, L. A., Larsen, M., Sarode, N., Thamdrup, B., and Stewart, F. J. (2015). Size-fraction partitioning of community gene transcription and nitrogen metabolism in a marine oxygen minimum zone. ISME J. 9, 2682-2696. doi: 10.1038/ismej.2015.44

Ganesh, S., Parris, D. J., DeLong, E. F., and Stewart, F. J. (2014). Metagenomic analysis of size-fractionated picoplankton in a marine oxygen minimum zone. ISME J. 8, 187-211. doi: 10.1038/ismej.2013.144

Garcia-Robledo, E., Padilla, C. C., Aldunate, M., Stewart, F. J., Ulloa, O., Paulmier, A., et al. (2017). Cryptic oxygen cycling in anoxic marine zones. Proc. Natl. Acad. Sci. U.S.A. 114, 8319-8324. doi: 10.1073/pnas.1619844114

Goldfine, H. (1984). Bacterial membranes and lipid packing theory. J. Lipid Res. 25, 1501-1507.

Goldfine, H., and Hagen, P. O. (1968). N-Methyl groups in bacterial lipids III. phospholipids of hyphomicrobia. J. Bacteriol. 95, 367-375. doi: 10.1128/JB.95. 2.367-375.1968

Gombos, Z., Várkonyi, Z., Hagio, M., Iwaki, M., Kovács, L., Masamoto, K., et al. (2002). Phosphatidylglycerol requirement for the function of electron acceptor plastoquinone QB in the photosystem II reaction center. Biochemistry 41, 3796-3802. doi: 10.1021/bi011884h

Grasshoff, K., Kremling, K., and Ehrhardt, M. (eds) (2009). Methods of Seawater Analysis. Hoboken, NJ: John Wiley \& Sons.

Harvey, H. R., Fallon, R. D., and Patton, J. S. (1986). The effect of organic matter and oxygen on the degradation of bacterial membrane lipids in marine sediments. Geochim. Cosmochim. Acta 50, 795-804. doi: 10.1016/00167037(86)90355-8

Harwood, J. L. (1998). "Membrane lipids in algae," in Lipids in Photosynthesis: Structure, Function and Genetics, eds P.-A. Siegenthaler and N. Murata (Dordrecht: Springer), 53-64. doi: 10.1007/0-306-48087-5_3

Helly, J. J., and Levin, L. A. (2004). Global distribution of naturally occurring marine hypoxia on continental margins. Deep Sea Res. Part I Oceanogr. Res. Pap. 51, 1159-1168. doi: 10.1016/j.dsr.2004.03.009

Herbert, R. A. (1999). Nitrogen cycling in coastal marine ecosystems. FEMS Microbiol. Rev. 23, 563-590. doi: 10.1111/j.1574-6976.1999.tb00414.x

Hölzl, G., and Dörmann, P. (2007). Structure and function of glycoglycerolipids in plants and bacteria. Prog. Lipid Res. 46, 225-243. doi: 10.1016/j.plipres.2007.05. 001

Imhoff, J. F. (1995). "Taxonomy and physiology of phototrophic purple bacteria and green sulfur bacteria," in Anoxygenic Photosynthetic Bacteria, eds R. E. Blankenship, M. T. Madigan, and C. E. Bauer (Dordrecht: Springer), 1-15. doi: 10.1007/0-306-47954-0_1

Jetten, M. S. (2008). The microbial nitrogen cycle. Environ. Microbiol. 10, $2903-$ 2909. doi: $10.1111 /$ j.1462-2920.2008.01786.x

Kalisch, B., Dörmann, P., and Hölzl, G. (2016). "DGDG and glycolipids in plants and algae," in Lipids in plant and algae development (Cham: Springer), 51-83.

Karl, D. M., Knauer, G. A., Martin, J. H., and Ward, B. B. (1984). Bacterial chemolithotrophy in the ocean is associated with sinking particles. Nature 309, 54-56. doi: 10.1038/309054a0

Karstensen, J., and Ulloa, O. (2019). Peru-Chile Current System. Amsterdam: Elsevier.

Kato, M., Sakai, M., Adachi, K., Ikemoto, H., and Sano, H. (1996). Distribution of betaine lipids in marine algae. Phytochemistry 42, 1341-1345. doi: 10.1016/ 0031-9422(96)00115-x

Kuypers, M. M., Lavik, G., and Thamdrup, B. (2006). "Anaerobic ammonium oxidation in the marine environment," in Past and Present Water Column Anoxia, ed. L. N. Neretin (Dordrecht: Springer), 311-335. doi: 10.1007/1-40204297-3_13

Lam, P., and Kuypers, M. M. (2011). Microbial nitrogen cycling processes in oxygen minimum zones. Annu. Rev. Mar. Sci. 3, 317-345. doi: 10.1146/ annurev-marine-120709-142814

Lavin, P., González, B., Santibáñez, J. F., Scanlan, D. J., and Ulloa, O. (2010). Novel lineages of Prochlorococcus thrive within the oxygen minimum zone of the eastern tropical South Pacific. Environ. Microbiol. Rep. 2, 728-738. doi: 10.1111/j.1758-2229.2010.00167.x
Lengger, S., Rush, D., Mayser, J. P., Blewett, J., Schwartz-Narbonne, R., Talbot, H., et al. (2020). Dark carbon fixation contributes to sedimentary organic carbon in the Arabian Sea oxygen minimum zone. Global Biogeochem. Cycles 33, 1715-1732. doi: 10.1029/2019gb006282

Logemann, J., Graue, J., Köster, J., Engelen, B., Rullkötter, J., and Cypionka, H. (2011). A laboratory experiment of intact polar lipid degradation in sandy sediments. Biogeosci. Discuss. 8, 3289-3321. doi: 10.5194/bgd-8-32892011

Makula, R. A. (1978). Phospholipid composition of methane-utilizing bacteria. J. Bacteriol. 134, 771-777. doi: 10.1128/jb.134.3.771-777.1978

Matys, E. D., Sepúlveda, J., Pantoja, S., Lange, C. B., Caniupán, M., Lamy, F., et al. (2017). Bacteriohopanepolyols along redox gradients in the humboldt current system off northern Chile. Geobiology 15, 844-857. doi: 10.1111/gbi.12250

Mehrbach, C., Culberson, C. H., Hawley, J. E., and Pytkowicx, R. M. (1973). Measurement of the apparent dissociation constants of carbonic acid in seawater at atmospheric pressure 1. Limnol. Oceanogr. 18, 897-907. doi: 10. 4319/lo.1973.18.6.0897

Molina, V., Belmar, L., and Ulloa, O. (2010). High diversity of ammonia-oxidizing archaea in permanent and seasonal oxygen-deficient waters of the eastern South Pacific. Environ. microbiol. 12, 2450-2465. doi: 10.1111/j.1462-2920. 2010.02218.x

Molina, V., and Farías, L. (2009). Aerobic ammonium oxidation in the oxycline and oxygen minimum zone of the eastern tropical South Pacific off northern Chile (20 $0^{\circ}$ S). Deep Sea Res. Part II Top. Stud. Oceanogr. 56, 1032-1041. doi: 10.1016/j.dsr2.2008.09.006

Molina, V., Ulloa, O., Farías, L., Urrutia, H., Ramírez, S., Junier, P., et al. (2007). Ammonia-oxidizing $\beta$-proteobacteria from the oxygen minimum zone off northern Chile. Appl. Environ. Microbiol. 73, 3547-3555. doi: 10.1128/aem. 02275-06

Moran, S. B., and Buesseler, K. O. (1992). Short residence time of colloids in the upper ocean estimated from 238 U-234 Th disequilibria. Nature 359, 221-223. doi: $10.1038 / 359221 \mathrm{a} 0$

Oliver, J. D., and Colwell, R. R. (1973). Extractable lipids of gram-negative marine bacteria: phospholipid composition. J. Bacteriol. 114, 897-908. doi: 10.1128/jb. 114.3.897-908.1973

Pantoja, S., Sepúlveda, J., and González, H. E. (2004). Decomposition of sinking proteinaceous material during fall in the oxygen minimum zone off northern Chile. Deep Sea Res. Part I Oceanogr. Res. Pap. 51, 55-70. doi: 10.1016/j.dsr. 2003.09.005

Parsons, T. R., Maita, Y., and Lalli, C. M. I. I. (1984). A Manual of Chemical and Biological Methods for Seawater Analysis, Vol. 1. Oxford: Pergamon Press, 73.

Passow, U., and De La Rocha, C. L. (2006). Accumulation of mineral ballast on organic aggregates. Global Biogechem. Cycles 20:GB1013.

Paulmier, A., and Ruiz-Pino, D. (2009). Oxygen minimum zones (OMZs) in the modern ocean. Prog. Oceanogr. 80, 113-128. doi: 10.1016/j.pocean.2008.08.001

Pearson, A., and Ingalls, A. E. (2013). Assessing the use of archaeal lipids as marine environmental proxies. Annu. Rev. Earth Planet. Sci. 41, 359-384. doi: 10.1146/annurev-earth-050212-123947

Petersen, S. O., Henriksen, K., Blackburn, T. H., and King, G. M. (1991). A comparison of phospholipid and chloroform fumigation analyses for biomass in soil: potentials and limitations. FEMS Microbiol. Lett. 85, 257-267. doi: 10.1111/j.1574-6968.1991.tb04732.x

Pierrot, D., Lewis, E., and Wallace, D. W. R. (2006). MS Excel Program Developed for CO2 System Calculations. ORNL/CDIAC-105a. . Oak Ridge, TN: Oak Ridge National Laboratory, 10.

Pitcher, A., Hopmans, E. C., Mosier, A. C., Park, S. J., Rhee, S. K., Francis, C. A., et al. (2011). Core and intact polar glycerol dibiphytanyl glycerol tetraether lipids of ammonia-oxidizing archaea enriched from marine and estuarine sediments. Appl. Environ. Microbiol. 77, 3468-3477. doi: 10.1128/aem.02 758-10

Pomeroy, L. R. (1974). The ocean's food web, a changing paradigm. Bioscience 24, 499-504. doi: 10.2307/1296885

Pomeroy, L. R., Williams, P. J. I., Azam, F., and Hobbie, J. E. (2007). The microbial loop. Oceanography 20, 28-33.

Popendorf, K. J., Lomas, M. W., and Van Mooy, B. A. (2011). Microbial sources of intact polar diacylglycerolipids in the Western North Atlantic Ocean. Organic Geochem. 42, 803-811. doi: 10.1016/j.orggeochem.2011.05.003 
Rattray, J. E., Geenevasen, J. A., Van Niftrik, L., Rijpstra, W. I. C., Hopmans, E. C., Strous, M., et al. (2009). Carbon isotope-labelling experiments indicate that ladderane lipids of anammox bacteria are synthesized by a previously undescribed, novel pathway. FEMS Microbiol. Lett. 292, 115-122. doi: 10.1111/ j.1574-6968.2008.01483.x

Rush, D., Hopmans, E. C., Wakeham, S. G., Schouten, S., and Damste, J. S. (2012). Occurrence and distribution of ladderane oxidation products in different oceanic regimes. Biogeosci. Discuss. 9, 2407-2418. doi: 10.5194/bg-9-2407-2012

Rütters, H., Sass, H., Cypionka, H., and Rullkötter, J. (2001). Monoalkylether phospholipids in the sulfate-reducing bacteria Desulfosarcina variabilis and Desulforhabdus amnigenus. Archiv. Microbiol. 176, 435-442. doi: 10.1007/ s002030100343

Sato, N., Hagio, M., Wada, H., and Tsuzuki, M. (2000). Requirement of phosphatidylglycerol for photosynthetic function in thylakoid membranes. Proc. Natl. Acad. Sci. U.S.A. 97, 10655-10660. doi: 10.1073/pnas.97.19. 10655

Schouten, S., Middelburg, J. J., Hopmans, E. C., and Damsté, J. S. S. (2010). Fossilization and degradation of intact polar lipids in deep subsurface sediments: a theoretical approach. Geochim. Cosmochim. Acta 74, 3806-3814. doi: 10.1016/j.gca.2010.03.029

Schouten, S., Pitcher, A., Hopmans, E. C., Villanueva, L., van Bleijswijk, J., and Sinninghe Damsté, J. S. (2012). Intact polar and core glycerol dibiphytanyl glycerol tetraether lipids in the Arabian Sea oxygen minimum zone: I. Selective preservation and degradation in the water column and consequences for the TEX86. Geochim. Cosmochim. Acta 98, 228-243. doi: 10.1016/j.gca.2012.05.002

Schubotz, F., Wakeham, S. G., Lipp, J. S., Fredricks, H. F., and Hinrichs, K. U. (2009). Detection of microbial biomass by intact polar membrane lipid analysis in the water column and surface sediments of the Black Sea. Environ. Microbiol. 11, 2720-2734. doi: 10.1111/j.1462-2920.2009.01999.x

Schubotz, F., Xie, S., Lipp, J. S., Hinrichs, K. U., and Wakeham, S. G. (2018). Intact polar lipids in the water column of the eastern tropical North Pacific: abundance and structural variety of non-phosphorus lipids. Biogeosciences 15, 6481-6501. doi: 10.5194/bg-15-6481-2018

Sebastián, M., Smith, A. F., González, J. M., Fredricks, H. F., Van Mooy, B., Kobližek, M., et al. (2016). Lipid remodelling is a widespread strategy in marine heterotrophic bacteria upon phosphorus deficiency. ISME J. 10, 968-978. doi: 10.1038/ismej.2015.172

Shaw, N. (1974). Lipid composition as a guide to the classification of bacteria. $A d v$. Appl. Microbiol. 17, 63-108. doi: 10.1016/s0065-2164(08)70555-0

Siegenthaler, P. A. (1998). "Molecular organization of acyl lipids in photosynthetic membranes of higher plants," in Lipids in Photosynthesis: Structure, Function and Genetics (Dordrecht: Springer), 119-144.

Sievert, S. M., Kiene, R. P., and Schulz-Vogt, H. N. (2007). The sulfur cycle. Oceanography 20, 117-123.

Sinninghe Damsté, J. S., Rijpstra, W. I. C., Geenevasen, J. A. J., Strous, M., and Jetten, M. S. M. (2005). Structural identification of ladderane and other membrane lipids of planctomycetes capable of anaerobic ammonium oxidation (anammox). FEBS J. 272, 4270-4283. doi: 10.1111/j.1742-4658.2005.04842.x

Sohlenkamp, C., López-Lara, I. M., and Geiger, O. (2003). Biosynthesis of phosphatidylcholine in bacteria. Prog. Lipid Res. 42, 115-162. doi: 10.1016/ s0163-7827(02)00050-4

Sollai, M., Hopmans, E. C., Schouten, S., Keil, R. G., and Sinninghe Damsté, J. S. (2015). Intact polar lipids of Thaumarchaeota and Anammox bacteria as indicators of $\mathrm{N}$ cycling in the eastern tropical North Pacific oxygen-deficient zone. Biogeosciences 12, 4725-4737. doi: 10.5194/bg-12-4725-2015

Stevens, H., and Ulloa, O. (2008). Bacterial diversity in the oxygen minimum zone of the eastern tropical South Pacific. Environ. Microbiol. 10, 1244-1259. doi: 10.1111/j.1462-2920.2007.01539.x

Stewart, F. J., Ulloa, O., and DeLong, E. F. (2012). Microbial metatranscriptomics in a permanent marine oxygen minimum zone. Environ. Microbiol. 14, 23-40. doi: $10.1111 /$ j.1462-2920.2010.02400.x

Sturt, H. F., Summons, R. E., Smith, K., Elvert, M., and Hinrichs, K. U. (2004). Intact polar membrane lipids in prokaryotes and sediments deciphered by highperformance liquid chromatography/electrospray ionization multistage mass spectrometry - New biomarkers for biogeochemistry and microbial ecology. Rapid Commun. Mass Spectrom. 18, 617-628. doi: 10.1002/rcm.1378

Suzumura, M. (2005). Phospholipids in marine environments: a review. Talanta 66, 422-434. doi: 10.1016/j.talanta.2004.12.008
Swan, B. K., Martinez-Garcia, M., Preston, C. M., Sczyrba, A., Woyke, T., Lamy, D., et al. (2011). Potential for chemolithoautotrophy among ubiquitous bacteria lineages in the dark ocean. Science 333, 1296-1300. doi: 10.1126/science. 1203690

Tamot, B., and Benning, C. (2009). "Membrane lipid biosynthesis in purple bacteria," in The Purple Phototrophic Bacteria. Advances in Photosynthesis and Respiration, Vol. 28, eds C. N. Hunter, F. Daldal, M. C. Thurnauer, and J. T. Beatty (Dordrecht: Springer), doi: 10.1007/978-1-4020-8815-5_7

Taylor, G. T., Iabichella, M., Ho, T. Y., Scranton, M. I., Thunell, R. C., MullerKarger, F., et al. (2001). Chemoautotrophy in the redox transition zone of the Cariaco Basin: a significant midwater source of organic carbon production. Limnol. Oceanogr. 46, 148-163. doi: 10.4319/lo.2001.46.1.0148

Thamdrup, B. (2012). New pathways and processes in the global nitrogen cycle. Annu. Rev. Ecol. Evol. Syst. 43, 407-428. doi: 10.1146/annurev-ecolsys-102710145048

Thamdrup, B., Dalsgaard, T., Jensen, M. M., Ulloa, O., Farías, L., and Escribano, R. (2006). Anaerobic ammonium oxidation in the oxygen-deficient waters off northern Chile. Limnol. Oceanogr. 51, 2145-2156. doi: 10.4319/lo.2006.51.5. 2145

Thamdrup, B., Dalsgaard, T., and Revsbech, N. P. (2012). Widespread functional anoxia in the oxygen minimum zone of the Eastern South Pacific. Deep Sea Res. Part I Oceanogr. Res. Pap. 65, 36-45. doi: 10.1016/j.dsr.2012.03.001

Ulloa, O., Canfield, D. E., DeLong, E. F., Letelier, R. M., and Stewart, F. J. (2012). Microbial oceanography of anoxic oxygen minimum zones. Proc. Natl. Acad. Sci. U.S.A. 109, 15996-16003. doi: 10.1073/pnas.1205009109

Ulloa, O., and Pantoja, S. (2009). The oxygen minimum zone of the eastern South Pacific. Deep Sea Res. Part II Top. Stud. Oceanogr. 56, 987-991.

Valentine, D. L. (2007). Adaptations to energy stress dictate the ecology and evolution of the Archaea. Nat. Rev. Microbiol. 5, 316-323. doi: 10.1038/ nrmicro1619

Van Mooy, B. A. S., and Fredricks, H. F. (2010). Bacterial and eukaryotic intact polar lipids in the eastern subtropical South Pacific: water-column distribution, planktonic sources, and fatty acid composition. Geochim. Cosmochim. Acta 74, 6499-6516. doi: 10.1016/j.gca.2010.08.026

Van Mooy, B. A. S., Fredricks, H. F., Pedler, B. E., Dyhrman, S. T., Karl, D. M., Koblížek, M., et al. (2009). Phytoplankton in the ocean use non-phosphorus lipids in response to phosphorus scarcity. Nature 458, 69-72. doi: 10.1038/ nature 07659

Van Mooy, B. A. S., Rocap, G., Fredricks, H. F., Evans, C. T., and Devol, A. H. (2006). Sulfolipids dramatically decrease phosphorus demand by picocyanobacteria in oligotrophic marine environments. Proc. Natl. Acad. Sci. U.S.A. 103, 8607-8612. doi: 10.1073/pnas.0600540103

Volkman, J. K., Jeffrey, S. W., Nichols, P. D., Rogers, G. I., and Garland, C. D. (1989). Fatty acid and lipid composition of 10 species of microalgae used in mariculture. J. Exp. Mar. Bio. Ecol. 128, 219-240. doi: 10.1016/0022-0981(89) 90029-4

Wada, H., and Murata, N. (1998). Membrane Lipids in Cyanobacteria. Lipids in Photosynthesis: Structure, Function and Genetics. Dordrecht: Springer, 65-81.

Wakeham, S. G., Amann, R., Freeman, K. H., Hopmans, E. C., Jørgensen, B. B., Putnam, I. F., et al. (2007). Microbial ecology of the stratified water column of the Black Sea as revealed by a comprehensive biomarker study. Org. Geochem. 38, 2070-2097. doi: 10.1016/j.orggeochem.2007.08.003

Wakeham, S. G., Turich, C., Schubotz, F., Podlaska, A., Li, X. N., Varela, R., et al. (2012). Biomarkers, chemistry and microbiology show chemoautotrophy in a multilayer chemocline in the Cariaco Basin. Deep. Res. Part I Oceanogr. Res. Pap. 63, 133-156. doi: 10.1016/j.dsr.2012.01.005

Walsh, D. A., Zaikova, E., Howes, C. G., Song, Y. C., Wright, J. J., Tringe, S. G., et al. (2009). Metagenome of a versatile chemolithoautotroph from expanding oceanic dead zones. Science 326, 578-582. doi: 10.1126/science.11 75309

Weijers, J. W. H., Schouten, S., Hopmans, E. C., Geenevasen, J. A. J., David, O. R. P., Coleman, J. M., et al. (2006). Membrane lipids of mesophilic anaerobic bacteria thriving in peats have typical archaeal traits. Environ. Microbiol. 8, 648-657. doi: 10.1111/j.1462-2920.2005.00941.x

White, D. C., Davis, W. M., Nickels, J. S., King, J. D., and Bobbie, R. J. (1979). Determination of the sedimentary microbial biomass by extractible lipid phosphate. Oecologia 40, 51-62. doi: 10.1007/BF00388810 
Wilson, J. D., Barker, S., and Ridgwell, A. (2012). Assessment of the spatial variability in particulate organic matter and mineral sinking fluxes in the ocean interior: Implications for the ballast hypothesis. Global Biogeochem. Cycles 26, 1-15. doi: 10.1029/2012GB00 4398

Wörmer, L., Lipp, J. S., Schröder, J. M., and Hinrichs, K. U. (2013). Application of two new LC-ESI-MS methods for improved detection of intact polar lipids (IPLs) in environmental samples. Organic Geochem. 59, 10-21. doi: 10.1016/j. orggeochem.2013.03.004

Wright, J. J., Konwar, K. M., and Hallam, S. J. (2012). Microbial ecology of expanding oxygen minimum zones. Nat. Rev. Microbiol. 10, 381-394. doi: 10. 1038/nrmicro2778

Xie, S., Liu, X. L., Schubotz, F., Wakeham, S. G., and Hinrichs, K. U. (2014). Distribution of glycerol ether lipids in the oxygen minimum zone of the Eastern Tropical North Pacific Ocean. Org. Geochem. 71, 60-71. doi: 10.1016/j. orggeochem.2014.04.006
Yao, M., Elling, F. J., Jones, C., Nomosatryo, S., Long, C. P., Crowe, S. A., et al. (2016). Heterotrophic bacteria from an extremely phosphate-poor lake have conditionally reduced phosphorus demand and utilize diverse sources of phosphorus. Environ. Microbiol. 18, 656-667. doi: 10.1111/1462-2920.13063

Conflict of Interest: The authors declare that the research was conducted in the absence of any commercial or financial relationships that could be construed as a potential conflict of interest.

Copyright (c) 2020 Cantarero, Henríquez-Castillo, Dildar, Vargas, von Dassow, Cornejo-D'Ottone and Sepúlveda. This is an open-access article distributed under the terms of the Creative Commons Attribution License (CC BY). The use, distribution or reproduction in other forums is permitted, provided the original author(s) and the copyright owner(s) are credited and that the original publication in this journal is cited, in accordance with accepted academic practice. No use, distribution or reproduction is permitted which does not comply with these terms. 